\title{
TOPYEKÜN TEMLtK
}

Doç. Dr. Fahrettin ARAL

\section{§ 1. GENEL OLARAK ALACAGIN TEMLIKI}

\section{I- Kavram}

Alacağın temliki Borçlar kanununda tanımlanmamıştır. BK m. $162 / I^{\prime}$ de alacağın temliki için borçlunun nzasına ihtiyaç olmadığı ifade edilmiştir. Buna göre, alacağın temliki, alacaklının bir borç ilişkisinden doğan alacağını, borçlunun rzasıma gerek olmadan, bir sözleşmeyle üçüncü bir şahsa devretmesi şeklinde tanımlanabilir (1). Böylece, alacakkı ile üçüncü şahıs arasında kurulan sözleşmeyle, alacaklı sıfatı alacaklıdan üçüncü şahsa geçmektedir (2).

Alacağın temlikinde, eski alacaklıya "temlik eden" (Zedent), alacağı iktisab eden üçüncü kişiye "temellük eden" (Zessionar), devredilen alacă̆ın borçlusuna "borçlu veya temlik edilen alacağın borçlusu" (abgetrener Schuldner; debitor cessus) denilir (3).

\section{II- Hukuki Mahiyeti:}

Alacă̆ın temliki hukuki niteliği itibariyle bir sözleşme, bir tasarruf sözleşmesidir:

\section{1- Alacağtn temliki bir sözleşmedir}

Alacağın temliki alacağı devreden alacaklının tek taraflı bir işlemi olmayıp, temlik edilenle temellük eden arasında kurulan bir sözleşmedir (4). Isviçre borçlar kanununun, BK m. 163/ II'ye tekabül eden, 165. maddesinin 2. fikrasının almanca metninde temlik sözleşmesi (Abtretungsvertrag) deyimi kullanılmıştır (5). Temlik sözleşmesi, Borçlar kanununda düzenlenmiş olmakla beraber, borç doğuran bir sözleşme değildir (6).

(1) von Tuhr/Eecher, sh. 329-330; Gubl/Merz/Kummer, sh. 231; Keller/Sch Bbi IV, sh. 43; Eren, C. III, sh. 414; Bucher, sh. 536; Gauch/Schluep II, N. 2175.

(2) Bu geçişin bir kanun hükmü (BK $\mathrm{m} .109$ ve 393/I) veya hir mahkeme kararıyla gerçekleşmesi halinde kanuni veya kazai temlik söz konusu olur (BK m. 164).

(3) von Twbr/Escher, sh. 390; Bucher, sh. 536; Keller/Sch8bi, IV, sh. 43; Gauch/ Sohluep, II, N. 2175; Eren, C. III, sh. 414-415; Guhl/Merz/Kummer, sh. 231.

(4) Gauch/Schluep, II, N. 2176; von Tuhr/Escher, sh. 330; Bucher, sh. 547-548; Eren, C. III, sh. 420 ; Ozuzmin $/ \mathcal{Z}$, sh. 408 . Karş. Engel, sh. 573.

(5) BGE 84 II 363 yahut JdT 1959 I, sh. 20I, cons. 1.

(6) von Tulur/Etcher, sh. 330; Eren, C. III, sh. 421. 


\section{2- Alacağ̀n Temliki Bir Tasarruf Sözleşmesidir}

Alacağmn temliki, alacağın temlik edenin mamelekinden temellük edenin mamelekine doğrudan doğruya geçişini sağlayan bir tasarruf sözleşmesidir (7). Bu itibarla temlik sözleşmesi, temlik edenin temlik edilen alacak üzerinde tasarruf yetkisine sahip olmasını şart kılar; tasarruf yetkisi temlik sözleşmesinin geçerlik şartını teşkil eder (8).

\section{III. Şartları}

Alacağın temlikinin şartlarını üç grupta toplamak mümkündür: 1- Hukuki sebep, 2- Temlik sözleşmesi ve 3- Temlik edjlebilir bir alacak.

\section{1- Hukuki Sebep}

Temlik, temlik edilen lehine bir kazandırmayı ihtiva eder. Tasarruf işlemi niteliğini taşıyan bu kazandırmanın hukukj sebebi bir temlik borcudur. Bu borç, bir sözleşmeden (temlik taahhüdü, BK m. 163 / II), bir ölüme bağlı tasarruftan (bir alacak vasiyeti) veya bir kanun hükmünden (BK m. 455/II) doğabilir (9). Temlik borcu doğuran sözleşme (mesela satım veya hibe) tasarruf işlemi olan temlike temel teşkil eder. Temlik taahhüdünün ihtiva ettiği hukuki sebep, ifa sebebi, bağışlama sebebi, alacak (veya iktisab) sebebi veya teminat sebebi şeklinde olabilir. Temlik taahhüdünün hukuki sebebi, alacağın temlikinin illî (sebebe bağlı) bir işlem olması sebebiyle büyük bir önem taşımaktadır. Zira geçerli bir hukuki sebep bulunmayan hallerde, temlik işlemi geçersiz olur.

\section{2- Temlik Sözleşmesi}

Yukarda da (II) ifade edildiği üzere, temlik sözleşmesi bir tasarruf sözleşmesi niteliğ̣ini ta̧̧ır.

\section{3- Temlik Edilebilir Bir Alacak}

Kural olarak, her alacak temlik edilebilir. Bu kuralın, kanundan, sözleşmeden ve işin niteliğinden doğan istisnaları vardır (BK m. 162 / I).

(7) von Tuhr/Escher, sh. 330, dn. 9 ve 10'a ait metin; Kellex/Schbbi, IV, sl. 45; Gauch/Schluep II, N. 2176; Bucher, sh. 547, 548; Eren, C.III, sh, 419; Ozuz$\operatorname{man} / 6 \mathrm{z}$, sh. 408.

(8) Keller/Schöbi IV, sh. 46; von Tuhr/Escher, sh. 331; Bucher, sh. 548; Eren III, sh. 419 .

(9) Gauch/Schluep II, N. 2180-2181. 


\section{$\S 2$. TOPYEKUN TEMLIKIN FONKSIYONU, TANIMI, HUKUKI NITELIGI VE ŞARTLARI}

\section{Topyekûn Temlikin Fonksiyonu}

Topyekûn temlik (Globalzession), kredi teminat aracı olarak başvurulan bir hukuki müessesedir. Bu itibarla kredi teminat işlemleri içinde önemli bir yer işgâl eder (1).

Kredi teminatları, muhtevalarna göre, biri aynî teminatlar, diğeri şahsî teminatlar olmak üzere başhica iki kategoriye ayrılır (2):

Aynî teminatlar (Realsichereiten), teminat altına alınan alacağa kavuşmak için, teminat konusu şey üzerinde, alacaklıya aynî bir hak sağlar. Böylece, alacaklı, alacağının ifasını sağlamak amacıyla, doğrudan doğruya hâkimiyetine tâbi kılınan teminat konusu şeyi paraya çevirme imkânına sahip olur (3). Bu tür teminatlara örnek olarak, menkul, gayrimenkul, alacak ve ticari işletme rehinlei iyle teminat amacıyla mülkiyetin inançlı devrini (Sicherungübereignung) zikredebiliriz (4).

Şahsî teminatlarda (Personalsichereiten) ise, üçüncü şahsın, borçlunun borcuna teminat olarak, alacaklıya karşı şahsi taahhütte bulunması söz konusudur. Başka bir ifadeyle, şahsł teminatta, teminat alan, aralarında mevcut bir borç iliģkisine istinaden, teminat verenden bir edimi veya kararlaş̧ırılan meblağı talep hakkına sahiptir (5). Böylece teminat veren üç̧üncü şahıs, haczedilebilen malvarlığının tamamıla sorumlu olmaktadır (6). Birlikte borç üstlenme (borca katılma), garanti sözleşmesi (BK m. 110) ve kefalet (BK 483) bu tür teminatlara örnek teşkil ederler.

(1) Zobl, Syst Teil, N. 1507 ve 1653 vd; ayns yazar, SJZ 1989, sh. 350; Emch/Renz, sh. 281; Bucher, sh. 538-539; Kleyling, sh. 7, 70 vd; Haensler, sh. 1 vd.

(2) T.Baer, sh. 3-4; Von Tuhr/Peter, sh. 140; Zobl, Syst Teil, N. 345 vd; ayni yazar, SJZ 1989, sh. 350; Kloiner, sh. 101; Kleyling, sh. 1; Gugenheim, sh. 147; Scyboz, sh. 22-25; Davran, sh. 3, 4; Tandoğan, C. II, sh. 688-689; Ozsunay, sh. 34; Haensler, sh. 13 vd.

(3) Gauch/Schluep/Tercier II, N. 2121-2122; Haensler, sh. 14, N. 13; Davran, sl. 3; Ozsumay, sh. 34 .

(4) Alacak rehninin hukuki niteliłği ile ilgili fa:klı görüşler için bk. Sirmen, sh. 5 vd; Ticari Işletme Rehni 28 Temmuz 1971 tarih ve 1447 sayılı kanunla kabut edilmiştir.

(5) Davran, sh. 3.

(6) T. Baer, sh. 4; Zobl, Syst T'eil, N. 346; Heendler, sh. 13, N. 12; Tandołann, C. II, sh. 689 . 
Bazı yazarlar (7) belirli bir mamelek objesinin bir alacağın teminatı olarak tahsis edilmesi olgusunu ifade etmek üzere, aynî teminat deyimini kullanmaktalar. Bunun sonucu olarak, teminat amacıyla alacağın inançlı temlikinin (Sicherungszession) aynî terminatlar arasında zikredildiği görülmektedir (8).

Kanaatimizce, fonksiyon ve amaçları bakımından aralarında benzerlik bulunmakla beraber, teminat amacıyla bir alacağın inançlı temlikinde teminat alan, aynì bir hak kazanmamaktadır. Bu itibarla, teminat amacıyla bir alacağın inanç̧ı devrini aynî teminatlar arasında zikretmek isabetli sayılamaz (9). Nitekim aynî teminatlar Medeni Kanunun ayni haklara ilişkin hükümlerinde (gayrimenkul rehni: MK m. 765-952; Menkul rehni: MK m. 853-894), alacağm temliki Borçlar kanununda (BK m. 162 vd) düzenlenmiştir. Binaenaleyh, teminat amacryla topyekün temlik ne aynî, ne şahsî temiratlar kategorisine girer. Banka uygulamalarmda, "diğer teminatlar" adıyla anılan üçüncü bir teminat kategorisine dahil sayllmaktadır (10).

Alacağın temliki, kapsamlarina göre ü̧̧ kısma ayrilır (11): münferit temlik, topyekün temlik ve çerçeve temlik.

I. Münferit temlik (Einzelzession), mevcut veya müstakbel belirli bir alacağın devredilmesidir. Bu tür temlikte her alacak bağımsız bir temlik işlemine konu olmaktadır (12). Meselâ satım veya istisna aktinden doğan alacağın temlik edilmesi.

2. Topyekuin temlik (Globalzession) ise, mevcut veya müstakbel alacakların tamamınn bir temlik işlemi çerçevesinde devredilmesidir.

(7) T. Baer, slı. 3-4; Albisetti/Boemle/Ehrsam/Gsell/Nyffeler/Rutschi, sl. 560.

(8) Oftigner/Baer, syst Teil, N. 330 vd; Zobl, SJZ 1989, sh. 350.

(9) Ayni fikirde; Haeneler, sh. 16-17, N. 16; Kleyling, sh. 2, 3. Bu yazar (sh. 3, dn. 13'e ait metin), temlik kredikerinin (Zessionkrediten) teminatsız kredilere nazaran (B)ankokrediten), hayat tecrübelerine göre daha büyük riskler tą̧dı̆ını jade etmektedir.

Gauch /Schtuep (N. 2455) teminat amacıyla inançlı devir ve temlik işlemlerini ayni ve şahsi teminatların yasunda aỵı bir kategori içinde mütalaa etmektedir. Teminat amacıyia inançlı devirde (Sicherungsübercignung), inantlan tam mülkiyet hakkı kazandı⿳્口̆ için, bu işlemlerle kurujan teminatları ayni teminatlar arasında zikretmek gerekir (bk, Oftinger/Baer, Syst Tejl, N. 235).

(10) Haensler, sh. 17, N. 1k.

(11) Zobl, Syst Teil, N. 1658 vd; Kleyling, sh. 24-25.

(12) Kleyllng, sh. 24; Zobl, Syst Teil, N. 1690. 
3. Cergeve temlik (Mantelzession), Almanya'da yaygın olarak uygulanan bir temlik türü olup, bununla temlik eden (kredi alan), bankaya karşı alınan kredi miktarınca cari alacaklarını devretmeyi taahhüt eder.

Münferit temlik ile topyekûn temlik arasında bir yer işgal eden çerçeve temlik, bir tasarruf işlemi olmayıp, temlik taahhüdü niteliği taşır. Kredi alan (temlik eden), imzalı temlik beyanlarını havi borçlu listelerini veya fatura kopyalarını, bankaya göndermek suretiyle, temlik taahhüdünüi ifa etmiş olmaktadır (13). Isviçre bankaları, temlik taahhüdünün BK m. 163/I gereğince yazılı şekle tabi olması ve topyekûn temlikin daha kuvvetli bir hukuki durum yaratması sebebiyle, çerçeve temlik yerine topyekûn temliki tercih etmektedir (14).

Teminat amaciyla yapılan temlikler içinde topyekûn temlik ön plânda yer almaktadır. Bununla, iktisaden güçlü olmayan ve nakit ihtiyacı içinde olan sınaî ve ticari işletmeler kredi temin etmek imkânı elde etmektedir (15). Kredi teminatı olarak gayrimenkule sahip olmayan işletmeler için müşteri alacakları (Kundguthaben) yegâne teminat aracıdır. Zira gerek menkul rehninde, gerek inançli devirde (Sicherungsübereignung), zilyetliğin devri gereklidir (MK m. 853). Keza MK m. 690'da öngörülen hükmen teslim yasağı, işletme teçhizatlan ile üretim vasitalarının teminat amacryla kullanılmasını engellemektedir (16). Bu bakımdan, ülkemizde teslimsiz menkul yașağına özel kanunlarla getirilen istisnalar arasında (17), 21.7.1971 tarih ve 1447 sayıl "Ticari Işletme Rehni Kanunu" ile kabul edilen ticari işletme rehni müessesesi önemli bir yer işgâl eder. Bu kanunla, küçük ve orta tacirler ile sanayicilerin ihtiyaçları olan kredileri bulabilme imkânı sağlanmıştır (18). Ancak, Ticari işletme rehni kanunu, ticari işletme rehniyle alacağı garanti edilecek §̧ahıslar bakımından bir sınırlama getirmiştir. Gerçekten, söz konusu kanunun, ticari işletme rehninde taraflar başlı̆ğın taşıyan, 2. maddesinin I. fikrasına göre, "ticari işletme rehni sözleşmesi, tüzel kişiliği haiz ve sermaye şirketi olarak kurulmuş kredi müesseseleri, kredili satı̧ yapan gerçek ve tüzel kişiliği haiz müesseseler ve kooperatifler ile ticarí işletmenin maliki

(13) Zobl, Syst Teil, N. 1688 vd; Kleylints sh. 25.

(14) Kleyling, sh. 25; Zobl, Syst Teil, N. 1688; Haensler, sh. 25, N. 11 ; Bucher, recht 1989, sh. 14.

(15) Zobl, Syst Teil, N. 1656, 1661 ; ayni yazar, SJZ 1989, sh. 350, dn. 9 ve 10'a ait metinler; Kleyling, sh. 70; Kaspex, sh. 110.

(16) Zobl, Syst Teil, N. 1656; ayni yazar, SJZ 1989, sh. 350.

(17) Bk. Koprtiliti/Kaneth, sh. 447 vd; Orarman/Seliçi, sh. 878 vd.

(18) Reisogrlu, Menkul ipoteği, sh. 22 vd, 73 vd. 
bulunan gerçek ve tüzel kişiler arasında yapılır". Ticari işletme rehni kanunu tasarısının gerekçesinde, "Bu tahdidin gayesi, menkuller üzerinde teslim vuku bulmaksızın tesis edilen rehnin mahzurlarını imkân nisbetinde önlemektir. Hakiki şahısların alacakları için de ticari işletme rehninin taninması halinde tatbikatta bunun suistimal edilmesinden endişe edilmektedir" denilmektedir (19). Bu suntrlama sebebiyle ticari işletme rehninin, teslimsiz menkul ipoteği yasağından (MK. m. 853) kaynaklanan güçlükleri tamamen bertaraf ettiğgini söylemek mümkün değildir (20).

Iktisadi amaçları ve teminat fonksiyonları itibariyle teminat amacyyla inançlı temlik ile alacak rehni (MK m. $868 \mathrm{vd}$ ) arasinda benzerlik bulunmaktadır (21). Ancak inançlı temlik, alacak rehninin aksine, fer'i teminat niteliği taşımaz (22). Inanç̧ temlikin, temlik konusu alacak üzerinde alacaklıya sağladığı tam hak (Vollrecht) ve alacağını kolaylıkla elde etme imkânı, uygulamada, özellikle bankaların yaptıkları kredi işlemlerinde, inançlı temlikin alacak rehnine tercih edilmesine sebep olmaktadır (23). Bu itibarla, taraflar arasinda yapılan teminat işleminin inançl temlik mi, yoksa alacak rehni $\mathrm{mi}$ olduğu hususunda ihtilaf çıarsa, şüphe halinde inançlı temlik lehine fiil: bir karinenin bulunduğunu kabul etmek gerekir (24).

\section{Topyekûn Temlikin Tanımı}

Topyekûn temlik (Globalzession), inançlı devredenin belirli bir faaliyet alanından doğan mevcut ve müstakbel alacaklarının tamammı

(19) Ticari tşletme rehni "Kanun projesi ve gerekçesi-proje hakkında görüşles-Komisyonun hazırladığı metin" Ankara 1965, sh. 66.

(20) Bu sınırlamanın tenkidi için bk, dn. 19'da zikredlen Tícari İ̧le'tme Rehni, sh. 34 35 (Prof. Dr. Turgut Kalpsüz) ve 43 (Dr. Serda Kurtoğlu).

(21) Bergmaier, sh. 72 vd; Zobl, Syst Teil, N. 1507; Oftinger/Baer, Syst 'Teil, N. 299 vd; Sirmen, sh. 40 .

(22) Zobl, Syst Teil, N. 1555; ayni yazar, SJZ 1989, sh. 351, dn.24'e ait metin; Oftinger/ Baer, Syst Teil, N. 302; Bergmaier, sh. 76; Wiegand, ZBJV 1980, sh. 561, dn. 60'a ait metin; Davran, sh, 4-5.

(23) Zobl, Syst Teil, N. 1507, 1536 vd; Ortinger/Baer, Sysi Teil, N. 273, 286; Wiegand, ZBJV 1890, sh. 560 vd; Kleln, sh. 208; Degrandi, SZW 1990/1, sh. 4; OxBunay, sh. 33.

(24) Oftinger/Baer, Syst Teil N. 286; Zobl, Syst Teil, N. 1538; Bergmaier, sh. 84 Bergmaier, eserinin başka bir yerinde (sh. 77-78, dn. 22'ye ait metin) farklı görüșü savunmaktadir Becker, Alt. 164, N. 12; Sirmen, sb. 41. Aksi fikirde: Wieland, Art. 900, N. 5; Leemann, Art. 900, N. 56. Kleyling (sh. 66) ise, şüple halinde. en azından kredi teminat işlemlerinde- temlikin bulunduơunu kabul etmek; işlemin mülnhasıran alacaklı lehine gerçekleştiogi hallerde (satım bedejinin bír alacakla temin edilmesi), alacak rehni lebine karar vermek, gerektiği fikrindedir. 
teminat amacıyla devretmesidir (25). Topyekûn temlik işlemi, genellikle temlik edenin standart muhtevalı bir metni imzalamasi şeklinde gerçekleşir; bu metin teminat alaşmassını (Sicherungsabrede) ve temlik işlemini ihtiva eder (26). Bankalar, verdikleri kredinin teminatını teşkil eden topyekûn temlik işlemine, ekseriya şu şartları derç ederler (27).

- Ticari faaliyetten doğan ve tịcari işletmeyle ilgili mevcut ve müstakbel alacakların devrine ilişkin genel bir temlik beyanı,

- Temlik edenin alacağın mevcudiyetini ve tahsil edilebilirliğini garanti etmesi,

- Temlik edenin alacağın ödenmesini garanti etmesi,

- Temlik edenin bütün faturaları banka nezdinde ödenmeye âmâde kılmak yükümü,

- Temlik edenin bankaya periyodik olarak borçlı listelerini göndermesi, hakk1,

- Bankanin temlik edenin defterini kontrol etme veya ettirme

- Temlik edenin kendisine doğrudan doğruya yapılan ödemeleri gecikmeksizin bankaya teslim (iletme) yükümü,

- Bankanın üçüncü şahıs borçlulara temliki her zaman ihbar ve alạcă̆ı bizzat tahsil etme hakkı.

\section{Topyeküin Temlikin Hnkuki Niteliği}

Topyekûn temlik hukuki niteliği itibariyle bir inançlı işlemdir (28). Bununla inanlan kendisine devredilen alacak üzerinde tam hak kazanır; tek başına tasarruf yetkisine sahip olduğu bu alacaktan dogan hakları, devredilen alacağın boşlusuna karşı ileri sürebilir (29).

Inanç anlaşmasıyla alacă̆ı devralanın tasarruf yetkisine getirilen sinırlandırma, sadece taraflar arasında borçlandınıcı etkiler doğurur;

(25) Zobl, Syst Teil, N. 1659; ayni yazar, SJZ 1969, sh. 351, dn. 19 a ait metin; Emch/ Renz, sh. 283.

(26) Zobl, Syst Teil, N. 1659; ayni yazar, SJZ 1989, sh. 351.

(27) Zobl, Syst Teil, N. 1660; ayni yazar, SJZ 1989, sh. 351; Bmch/Renz, sh. 284.

(28) Zobl, Syst Teil, N. 1551 ; ayni yazar SJZ 1989, sh. 351; Jaeggi/Gauch, Art. 18, N. 187; Kramer, Art. 18, N. 121; Bergmaler, sh. 30 vd; Oberlin, sh. 70 vd; Eren, C.I, sh, 443.

(29) Jaegg//Gauch, Art. 18, N. 188; Kramer, Art. 18, N. 119; Von Tuhr/Eecher sh. 340; Zobl, Syst Teil, N. 1553; Eren, C. I, sh. 935; Oberlin, sh. 74. 
bu borca aykırllik onu $\mathrm{BK} \mathrm{m}$. 96 vd gereğince tazminat ödemekle yükümlü kılar (30).

Inançlı işlemler, takibedilen gaye açısından, "saf inançh mua* meleler" (reine fiduziarische Rechtgeschaefte) ve "karma inançlı muameleler" (gemischte fiduziarische Rectsgeschaefte) şeklinde ikiye aynlır. Doktrinde en fazla taraftar toplayan (31) bu ayırım Roma hukukunun fiducia cum amico-fiducia cum kreditore örneklerine dayanır (32). Saf inançh muamelelerde inamılan inanç konusunu tamamen ve münhasıran inanan yararna elinde bulundurduğu halde, karma inançl muamelerde esas itibariyle inanılanın yararı ön plânda gelmektedir (33). Bu itibarla, bir alacağın teminat amacıyla temliki, dolayısıyla topyekûn temlik işlemi, karma inançlı işlemler kategorisine girer (34).

\section{IV- Topyekun Temlikin Sartlari}

Topyekun temlikin başıca üç şartı vardır: Teminat anlaşması, teminat anlaşmasınun icrası (tasarruf işlemi olarak temlik) ve temlik edenin tasarruf yetkisine sahip olmasıdır (35).

\section{A) Teminat Anlasmast (pactum fiduciae; Sicherungsabrede):}

Teminat anlaşması, inançh temlike esas teşkil eden bir borç doguran işlem olup, başlıca iki fonksiyon icra eder. Bu fonksiyonlardan birincisi temlik işleminin hukukî sebebini ihtiva etmek, diğeri ise inanan ile inanılan arasındaki iç ilişkiyi, özellikle inanılanın haiz olduğu hukuki yetki ile teminat konusumun inana iade edilme şartlarını belirlemektir (36). Baskka bir ifadeyle, teminat anlaşmasının muhtevasinı, temlikin hukuki sebebi ile tarafların karşılıkı hak ve borçları teşkil eder.

(30) Jaeggi/Gauch, Art. 18, N. 189; Kramer, Art. 18, N. 119; Zob1, Syst Teil, N. 1554; Oberlin, sh. 80; Keller/Schbbi IV, sh. 47, 52; Merz, legalzession, sh. 453, 457; Eren, C.I, sh. 446.

(31) Bergmaier, sl. 32, 33; Reymond, Nr. 12 ve 31; Waell, sh, 20; Oxsunay, sh. 43; Eren, C.I, sh. 443. Bk ve kars. Rüede-Bugnion, sh. 53.

(32) Bergmaier, sh. 33, dn. 9; Ozsunay, sh. 43.

(33) Orsunay, sh. 45, 57; Waell, sh. 19; Eren, C.I, sh. 443.

(94) Bergmaier, sh. 33; Ozemany, sh. 57; Eren, C. I, sl. 443.

(35) Zobl, Syst Teil N. 1556 vd; ayni yazar, SJZ 1989, sh. 351. Ayrica bk. Ozerunay, sh. 61, 62; Bergmaier, sh. 33 vd.

(36) Zobl, Syst Teil N. 1374; ayni yazar, SJZ 1989, sh. 351. Ayrica bk. Bergmaier, sh. 67-68; Kramer, Art. 18, N. 124. 
Genel olarak inançlı işlem sözkonusu olan hallerde teminat anJaşması yerine "inançlı tẹmel işlem" (die fiduziarische Grundgeschaft) deyimi kullanılmaktadır (37). Ancak, teminat amacıyla yapılan inançlı temliklerde teminat anlaşması deyiminin kullanılmasınm uygun olacağı kanaatindeyiz.

Teminat (inanç) anlaşmasının hukuki niteliğ konusunda değişik fikirler ileri sürülmektedir.

Bazı yazarlará göre (38), teminat (inanç) anlaşması hukuken, bir vekâlet veya en azından vekâlet benzeri jlişki sayılır. Bu sonuç, BK m. 386/II'den çıłmaktadır.

Buna karşılık, bizim de katıldığımız hâkim fikre göre (39), teminat (inanç) anlaşması, bir sui generis veya isimsiz sözleşmedir. Zira teminat (inanç) anlaşmass kanunda düzenlenmedił̆i gibi, kanunda öngörülen akit tiplerine de dahil edilemiyen bir sözleşme türüdür. Çok cepheli inançlı işlemlerin sadece vekâlete ilişkin kurallara tabi tutulması isabetli olmaz.Keza, vekâlet akdinin başlıca özelliklerinden olan, vekilin müvekkilin talimatına uygun hareket yükümü (BK $\mathrm{m}$. 389) ve tek taraflı geri alma (Widerruf; azil) hakkını kullanmak suretiyle müvekkilin vekâlet akdini her zaman sona erdirebilme imkânı (BK m. 386/I), inançlı işlemlere hâkim olan temel düßsüncelerle bağdaşmaz $(40)$. Bununla beraber, idare amaciyla yapilan inanç̧ı devir sözleşmeleri (Verwaltungstreuhandvertrag) nin hukuken vekâlet niteliği taşıdığı kabul edilmektedir (41).

Teminat amacryla bir alacă̆ın inançlı devri ile, inanılan devir edilen alacak üzerinde tam hak kazandığı için, söz konusu temlik bir kazandırıcı işlem niteliği taşır (42). Her kazandırıcı muamele gibi,

(37) Bk. Bergmaier, sh. 67 vd; Oberlin, sh. 70 Bk. ve kars. Jeeggi/Gauch, Art. 18. N. $178 \mathrm{vd}$; Gauch/Schluep, I, N. 756-759.

(38) Gautschi, Art. 394, N. 13a; Jaeggi/Gauch Art. 18, N. 179; BGE 99 II 397 yahut JdT 1974 I 591-592, cons. 6.

(39) Zobl, Syst Teil, N. 1376, 1557; Guh1/Merz/Kummer, sh. 295; Raymond, sh. 39; Bergmaier, sh. $69 \mathrm{vd}$; Oberlim, sh. 71, 77 .

(40) Zobl, Syst Teil, N. 1381; Rtede-Bugnion, sh. 58; Kadert, sh, 114, dn. 1'e ait metin; Waelli, sh. 83, 86; Oberlin, sh, 71 .

(41) BGE 106 Ib 150; Merz, legalzession, sh. 453 vd; Zobl, Syst Teil, N. 1376, 1380; Oberlin, sh. 71.

(42) Bergmaier; sh. 43 vd; Waelli, sh. 25 vd, 49 vd; Jaeggi Ganch, Art. 18, N 185; Reymond, Nr. 38; Czsunay, șh. 85 vd; Tandogran, G. II, sh. 546. Buna karq̧ulı, bazı yazailar inançl işlemlerde ciddî olarak istenilen bir kazandırıcı işlemin olma* dığ fïkrindedir (bk. von Büren, I, sh. 174-175; Schbmle, sh. 39 vd). 
bir tasarrufî kazandırma olan inançlı temlik de, bir gayeye erişmek için yapılı. Tarafların üzerinde anlaştıkları bu gayeye Roma hukukı ve müşterek hukuktan gelen bir tabirle "causa" (hukuki sebep) denir (43). Başka bir ifadeyle, hukuki sebep (causa) deyimi, gaye anlaşması, yani taraflarca kararlaştırılan gaye anlamına gelir (44). Bunuıla beraber, isviçre/Türk hukukunda, istisnaen sadece kazandıranın iradesiyle tek taraftı olarak hukuki sebebin tayin edildiği haller de vardır; vasiyetname ile yapılan kazandırmalarda, vakıf kurma işleminde, aleni mükafaat vaadinde (BK m.8) vekâletsiz isgoörmede ve alacaklnnın iştirakine gerek olmayan ifada durum böyledir (45).

Kazandiricı muamelenin sebepleri, genellikle, causa solvendi ( =ifa sebebi), cause credendi veya acquirendi (iktisab veya karşı kazandırma elde etme sebebi) ve causa donandi (bağışlama sebebi) olmak üzere başhıca üç gruba ayrılır. Ancak Roma hukukundan gelen bu tasnif tahdidî değildir (46). Teminat amacryla yapılan inançlı temlikin hukuki sebebi "teminat sebebi"dir (47).

Bazı yazarłar (48), teminat anlaşmasının, teminat amacıyla inançl temlikin hukuki sebebini teşkil ettiğini; tasarruf işlemi olan alacağın temlikine (causa olarak) dayanak teşkil eden temel işlem niteliğini taşıdığını ifade etmekteler. Bu takdirde, hukuki sebep (causa) kavramı, gaye anlaşmasının ilişkin bulunduğu kazandırıc işleme (temlike) esas tę̧kil eden "borç" veya bu borcu doğuran "borç kaynağı", "temel münasebet" anlamında kullanılmıs olmaktadı (49). Bu anlayıs,, "ilmî ve teknik bakımdan doğru değildir. Çünkü bir satım akti veya semen borcu için ifa (erfüllungshalber), tecdit, inançl muameleyle temin veya tesbit gibi muhtelif hukuki sebeplerle kazand'ricı muamelede bulunulabilir" $(50)$.

(43) Sungurbey, sh. 4; Oxsunay, sh. 89-90.

(44) Sungurbey, sh. 4; von Tuhr/Peter, sh. 203; Kocayusufpaşaoğlu, Borçlar Hü. kuku, sh. 130 .

(45) Sungurbey, sh. 4; von Tuhr/Peter, sh. 203, dn. 14b; von Tuhr, Allg. Teil BGB, $\S 72$ III, sh. 80-81; Kocayusufpaşaoğlu, Borçlar Hukuku, sh. 130, dn. 43; Oz* sunay, sh. 90.

(46) Sungurbey, sh. 5; von Tuhr/Peter, sh. 200; Bergmaier, sh. 53; Kocayusufpaşaoglu, sh. 131; Ozsunay, sh. 90-91.

(47) Sungurbey, sh. 5/6; Bergmaier, sh. 47 vd; von Tuhr (sh, 200, dn 9'a ait metin) alacăğı temini amacıyla yapılau kazandırmaları causa solvendi'ye (ifa sebebine) dabil etmektedir.

(48) Flume, II, sh. 155-156; Gauch/Schluep II, N. 2180; Bucher, sh. 559, dn. 94; Zobl, Syst Teil, N. 1566.

(49) Sungurbey, sh. 7 .

(50) Sungurbey, sh. 7. Ayrica bk. Enneccerus/Nipperdey, sh. 91t, di. 5; Özsunay, sh. 91 . 
Ayni şekilde, bir hukuki sebep olarak kabul edilen "causa fiduciae" deyimi (51) de teminat amacıyla alacağmn temlikinde hukuki durumu yeterli açılıkta belirtmekten uzaktır.

B) Teminat Anlaşmasınn Ifast (Tasarruf muamelesi olarak temlik) :

Bir taahhüt muamelesi olan teminat anlaşmasının ifasi $B K=$ 163/I anlamında alacağın temliki sözleşmesiyle gerçekleşir. Alacă̆ın temliki, akdi nitelikte bir tasarruf işlemidir. Bununla, temlik edilen alacak, devrenin mamelekinden çrkup devralanın mamelekine geçer (52).

Akitlerin kurulmasına ilişkin BK m. 1-40'da yer alan hükümler, özellikle karşılıklı irade beyanlarının uygunluğuna, akitlerin konusuna, irade sakatllğına ve temsile ilişkin hükümler ,bir borçlar hukuku sözleşmesi olan temlik sözleşmeșine de uygulanır (53).

BK m. 163/I gereğince temlik sözleşmesi yazılı şekilde yapılmak zorundadır; yazılı şekil sözleşmenin geçerlik şartını teşkil eder (54). Burada söz konusu olạn şekil, âdi yazılı şekildir; sadece alacağı temlik edenin irade beyamının kanuni şekil içinde gerçekleşmesi yeterlidir (BK m. 13) (55).

Kanun, şekil şartını hukuki güvenlik sebebiyle öngörmüş bulunmaktadır; şeklin amacı, özellikle üçüncü kişileri ve borçluyu temlik olayından haberdar etmektir (56). Bununla beraber, alacağın temlikinde alacaklının ismen zikredilmesi şart değildir; "açığa veya beyaza temlik" (Blankozession) geçerlidir; bu tür temlikte alacağı iktisab edecek kişinin kimliği bir başkası tarafından, özellikle temellük eden tarafindan yazılip beliplenebilir (57).

(51) Wolff, sh. 69-70; Ozsunay, sh. 91, dn. 33 ve buna ait metin.

(52) von Tuhr/Escher, sh. 330; Keller/Schobi IV, sh. 45; Gauch/Schluep II, N. 2176; Zobl, Syst Teil Ni. 1579; Bucher, sh. 547; Eren, C. III, sh. 419.

(53) von Tuhr/Escher, sh. 330; Zobl, Syst Teil N. 1579; Bucher, sh. 548; Bergmaier, sh, 39; Eren, C. III, sh. 421 .

(54) von Tuhr/Eacher, sh. 330; Zobl, Syst Teil N. 1581; Gauch/Schluep II, N. 2178; Eren, C. III, sh, 425.

(55) Gauch/Schluep II, N. 2178; Keller/Schöbi, IV, sh. 44, 45; Bergmaier, sh. 40; Eren, C. III, sh. 425-426.

(56) von Tuhr/Escher, sh. 334-335, dn. 49'e ait metin; Keller/Schbbi, IV, sh. 44; Zobl, Syst Teil, N. 1581; Becker, Art. 165, N. 2; Bucher, sh. 550; Engel, sh. 590; Eren, C. III, sh. 425; BGE 90 II 179; 88 II 2 I.

(57) von Twhr/Escher, sh. 335-336; Engel, sh. 591; Ganch/Schluep, II, N. 2266; Bucher, sh. 551; Keller/Schbbi, IV, sh. 45; Kramer, Allg, Einleitung, N. 76; Zobl, Syst Teil, N. 158]; Eren, C. III, sh. 425; BGE 82 II 52. 
Alacağın temlikinin sebebe bağl (illî̀) bir işlem olup olmadığı tartışmalıdır.

Önceleri Isviçre hukukunda eğemen olan bir görüşe göre (58), bütün tasarruf işlemleri gibi, bir tasarruf işlemi olan alacağın temliki de soyuttur. Soyutluk ilkesi kabul edildiği takdirde, temeldeki borçlandırıcı işlem geçersiz olsa dahi, temlik işlemiyle alacak temellük edene geçer; ancak bu geçiş, geçerli bir sebebe dayanmadığından, temlik eden sebepsiz zenginleşme davasıyla devrettiği alacağın kendjsine devrini sağlar (59). 13viçre Federal mahkemesi eski kararlarında alacağın temlikinin soyut bir işlem olduğunu kabul ettiği (60) halde, yeni kararlarında (61) sorunu cevapsız (açık) bırakmıştır.

Buna karşhlik günümüzde hâkim olan diğer bir görüşe görẹ (62), alacağın temliki sebebe bağlı (illî) bir işlemdir. Biz de bu görüşe katulmaktayız. von Tuhr tarafindan ileri sürülen (63), bütün tasarruf işlemlerinin soyutluğu görüşünün Isviçre/Türk hukuku bakımindan isabetli olduğu söylenemez. Zira hukukumuzda en önemli tasarruf muamelesi olan taşınmaz mülkiyetinin devrinin sebebe bağlı olduğu MK m. 932 ve 933 'te hükme bağlanmıştır. Ayni esasın taşınır mülkiyetinin devrinde geçerli olduğu doktrin ve yarg ${ }_{1}$ kararlarnnca kabul edilmiştir (64).

Alacağın temliki sebebe bağh (illi) bir islem olarak kabul edilince, geçerli bir hukuki sebebin bulunmaması halinde, alacak, temlik edilene geçmez; devredenin yeniden alacağa sahip kılınması söz konusu değildir; $o$, ancak temellük edenden verdiği temlik belgesinin iadesini veya iptalini isteyebilir. Devreden ancak, borçlunun temellük edene ödemede bulunması veya iyiniyetli üçüncü şahsın devredi-

(58) von Tuhr/Escher, sh. 333; Bucher, sh. 544 vd; Oser/Schoneneberger, Art 164 N. 3; Becker, Art. 164, N. 1; Schmid, W.D., SJZ 1970, sh. 299 vd.

(59) Gauch/Scbluep, II, N. 2240; Jaeggi, SJZ 1971, sh. 6; Eren, C. III, sh, 422.

(60) JGGE 50 II 154; 50 II 393; 67 II 127; 71 II 169 vd.

(6i) 13GE 84 II $363 ; 95$ II 112.

(62) Jaeggi, SJZ 1971, sh. 7; Moecke, H-J, Kausalc Zession und gutglaubiger Iorderungegserwerb, Freiburg in CHI, sl. 97; von Büxen, I, sh. 318; Engel, sh. 594; Merz, Vertrag und Vertragsschluss, sh. 45; Dutoit, sh. 453 vd; Guhl/Merz/Kummer, sh. 235; Gauch/Schluep, II, N. 2239 vd; Jeanpretre, SJZ, 1967 sh. 19; Eren, C. III, sh. 423 .

(63) von Tuhr/Escher, sh. 333.

(64) Eren, C. III, sh. 423; Merz, Vertrag und Vertragsschisuss, sh. 45, dn. 60'a ait metin. 
len alacağı iktisap etmesi hallerinde temellük edene karşı sebepsiz zenginleşme davası açabilir (65).

C) Temlik edenin tasarruf yetkisine sahip olmast

Alacağın temliki bir tasarruf işlemi oldư̆u için, temlik edenin alacak üzerinde tasaruf yetkisinin bulunması gerekir; tasarruf yetkisinin bulunmaması halinde, temlik işlemi geçersiz olur (66).

Kural olarak, temlikin yapıldığı anda alacaklının tasarruf yetkisine sahip olması gerekir. Alacağın temlik edenin mamelekinde yer alması veya başkasının mamelekine dahil olan bir alacak temlik edilecekse temlik edenin yetkili kılınması hallerinde bu şart gerçekleşmiş olur. Yetkisiz temsilcinin yaptı̆̆ı temlik, alacaklının sonradan icazet vermesiyle veya temlik edenin sözkonusu alacağı sonradan iktisab etmesiyle geçerlilik kazanır (67).

Birden ziyade temlik halinde, tasarruf işlemlerinde geçerli olan "zaman itibariyle öncelik" prensibi gereğince ilk temlik geçerli ohur(68).

(65) Jaeggi, SJZ 1971, sh. 6, 7; Gauch/Schluep, II, N 2443; Eren, C. III, sh. 422.

(66) Bucher, sh. 548; von Tuhr/Escher, sh. 331; Keller/Schsbi, IV, sh. 46; Cauch/ Schluep, II, N. 2176; Eren, C. III, sh. 419.

(67) von Tubr/Escher, sh. 331; Keller 'Schöbi, IV, sh. 46; Bucher, sh. 548; Eren, C. III, sh. $420-421$.

(68) Gauch/Schluep, II, N. 2176; Bucher, slt. 548. dn. 50 ve buna ait metin; Eren, C. III, sh. 420 . 


\section{§ 3. TOPYEKÜN TEMLIKIN KONUSU}

Topyekûn temlikin konusunu temlik edilebilir alacaklar teşkil eder. BK m. 162/I hükmüne göre, kanun, akit veya hukuki ilişkinin niteliği gereği temliki yasak olmayan her türlü alacaklar temlikin, dolayısıyla topyekûn temlikin konusunu teşkil eder. Temlik edilcı alacağı doğduğu borç kaynağı önemli değildir. Akitten, haksız fiilden, sebepsiz zenginleşmeden veya vekâletsiz işgörmeden doğan alacaklar temlik edilebilir. Ayni şekilde eşya, miras veya aile hukukundan doğan alacaklar da temlike konu olabilir (1).

Topyekûn temlikin konusuna giren alacaklar, mevcut alacaklar, müstakbel alacaklar ve şarta veya süreye bağlı alacaklar olmak üzere üç grupta toplanabilir.

\section{1- Mevcut Alacaklar}

Mevcut alacaklar, temlikin yapıldığı anda hukuken doğmuş bulunan alacaklardır. BK m. 162/ I ve MK m. 23'de öngörülen sınırlar içinde kalınmak şartıyla, bu tür alacakların topyckûn temlik çerçevesinde temlik edilmeleri herhangi bir sorun yaratmamaktadır.

\section{2- Şarta ve Süreye Bağlı Alacaklar (bedingten und befris- teten Forderungen)}

Şart, tarafların iradesiyle bir işlemin hukuki etkisinin doğumunun ve ortadan kalkmasının gelecekte gerçekleşmesi şüpheli bir olaya bağlanmasılır (2). Süre tayini (Befristung) ise, taraflarm hukuki işlemin sonuç doğurmasını veya sonuçlarının ortadan kalkmasmı gelecekteki gerçekleşmesi kesin bir olaya bağlamasıdır (3).

Şarta ve süreye bağlı alacaklar topyekûn temlik çerçcvesinde üçüncü şahıslara devredilebilir (4)

(1) Bk. Gauch/Schluep, Il, N. 2184, $2185 ;$ Guhl/Merz/Kummex, sh. 234; Eren, C. 11I, 428; Kellex/Schöbi, IV, sh. 56 .

(2) bk. Merz, SPR VI/1, sh. 148; Pulaşlı, sh. 8; Fume, sh. 677; Bucher, sl. 507; Eren, Ci. III, sh, 343-344.

(3) bk. Merz, SPR V1/1, sh. 152-153; Pulaģlt, sh. 70; Sirmen, \$art, sh. 87; Eren, C.III, sh. 349 .

(4) bk. Zobl, Syst Teil, N. 1569; von Tuhr/Escher, sh. 348; Guhl/Merz/Kummer, sh. 235. Bazı yazarlardán (dn.11), taliki șarta ve süreye bağlı alaçakları müstakbel alacak sayarken, diğerleri (dn.12), bu tür alacakları nevcut alacaklar içinde mütalain etmoktedir. Bu konuda bk, bu parağraf, 3). 


\section{3- Müstakbel Alacaklar}

Müstakbel alacak (künftige Forderung; creance future) kavram1, MK m. 796/I (ZGB Art. 824/I) ve BK m. 485 (OR Art. 492/II)'de sadece 'smen zikredilmiştir. Bunun dışında, müstakbel alacağın kanuni bir tanımı yapılmamış bulunmaktadır.

Müstakbel alacaklar doktrinde başlıca iki kısma ayırılmaktadır (5): Bunlardan birincisi, temlikin yapıldığ 1 anda mevcut olan bir hukuki ilişkiye dayanan müstakbel alacaklardır. Meselâ, temlikin yapıldığı anda mevcut bir kira aktinden ilerde doğacak kira alacaklarınin temliki (6). Diğeri ise, temlikin yapıldığı anda henüz mevcut olmayan bir hukuki ilişkiden doğacak alacaklardır. Henüz kiraya verilmemiş bir evin ilerde kiraya verilmesinden doğacak kira alacağının; ileride kurulacak bir satım aktinden doğacak satı̧ bedelinin temlikinde durum böyledir (7).

Bununla beraber, bazı yazarlar (8), her iki kısım arasında bir ayırım yapmaksızın, müstakbel alacak deyimini kullanmaktadır.

Buna karşılık, geciktirici (talikî) şarta bağlı alacaklar (die suspensiv bedingten Forderungen) (9) ile geciktirici süreye bağlı alacaklarin (die suspensiv befristeten Forderungen) (10), mevcut veya müstakbel alacaklar grubundan hangisine dahil olduğu tartısmalıdır.

Bir fikre göre (11), geciktirici şarta ve geciktirici süreye bağlı alacaklar, müstakbel alacaklar kategorisine girer. Zira doğuş şartlarından biri eksik olan alacaklar, müsıakbel alacak saylır.

(5) von Tuhr/Escher, sh. 348-349; Kleyling, sh. 72; Haensler, sh. 35-36; Becker, Art. 164, N. 15; Hahnrog, sh, 20.

(6) ven Tuhr/Escher, sh. 348; Haensler, sh. 35.

(7) Bu tür alacaklara, "dar anlamda müstakbel alacaklar" (von Tuhr/Escher sh. 349; Kleyling, sh. 72; Hahnzog, sh. 22) veya "ümit edilecek alacaklar" (gehoffte Forderungen) (Fromer, sh. 284) da denilmektedir.

(8) Guhl/Merz/Kummex, sh. 235; Gauch/Schluep, II, N. 2197; Keller/Schöbi, sh. 56. Zobl ise (Syst Teil N. 1570) "doğumu tamamen gelecekte bulunan alacaklar" deyimine üstünlük tanımaktadır.

(9) Bozucu şarta bağlı alacaklar, hukuki ișilemin kurulduğu anda mevcut olup, sonradan şartın gerçekleşmesiyle ortadan kalktıklam için, mevcut alacaklar kategorisine girer. bk. Habnzog, sh. 14-15; Haensler, sh. 36, dn. 5. Fromer, sh. 277, dn. 11.

(10) Bozucu süreye bağlı alacaklar, hukuki işlemin kurulduğu anda anda mevcut olup, sürenin dolmasıyla ortadan kalktıkları işin, nevcut alacaklardan sayılır. bk. Hahnzog, sh. 14-15; Haensler, sh. 36, dr. 6 .

(11) von Tuhr, Verfügungen über künftige Forderungen DJZ 1904, sh 428; Hahnzog, sh. 5, 15; Kleyling, sh. 72; Oser/Schoneneberger, Art. 164, N. 4; Sirmen, Alacak Rehni sh. 15 ve Hahnzog, sh. 15, dn. 44, zikredilen diğer yazarlar. 
Buna karşlık diğer bir fikre göre \{12), geciktirici şarta ve geciktirici süreye bağlı alacaklar mevcut alacaklar kategorisine dahildir. BK m. 485 (OR art. 492/II)'da müstakbel alacaklar ile şarta bağh alacakların karşı karşıya konulmasının bu görüşü desteklediği ifade edilmektedir. Bu iddiaya karşı, kanunun anılan maddesinde, kanun koyucunun sadece şarta bağlı alacaklarla ile müstakbel alacakların mevcut alacakların karşıtıı teşkil ettiğinc işaret etmek istediği söylenebilir (13).

Taliki şarta bağlı alacaklar yapıları itibariyle müstakbel alacaklardan ayrılır (14) BK m.150 anlamında şartta, alacağın geçerliliği tarafların seçtiği meşkûk bir olayın gerçekleşmesine bağlanmıştır (15). Böylece taraflar aslında alacağın doğumu için kanunen gerekli olmayan bir olguyu alacağın doğuş şartı durumuna getirmiştir. Oysa müstakbel alacaklarda alacağın doğumu, alacağın doğması için kanun gereği bulunması gereken bir olgunun gerçekleşmemesi sebebiyle engellenmektedir. Böylece müstakbel alacak, alacağın varlığını mümkün kılan bir zorunlu kanuni olgunun zuhuru ile doğmaktadır (16).

Geciktirici süreye (vadeye) bağlı alacaklarm geciktirici şarttan ayrıldığ1 yegâne nokta, geciktirici sürelerde alacağın doğumuna imkân veren olayın gerçekleşmesinin kesin olmasıdır (17).

Geciktirici şarta ve geciktirici süreye bağlı alaçakların doğumunun ileriye burakılması tarafları iradesine (mutabakatına) dayandığı halde, müstakbel alacakların doğumunun gelecekte gerçekleşmesi kanuni bir zarurete dayanmaktadır (18). Ayı şekilde, müstakbel alacağın alacaklısının aksine, şarta bağlı hak sahibi şartın gerçekleşmesinden önce muntazar hak sahibi durumundadır. Hakkın tehlikeye düşmesi halinde, alacağı şarta bağlı olmayan alacaklı gibi koruma tedbirleri talep ediebilir (BK m. 150/II) (19).

Bu itibarla, geciktirici şarta ve geciktirici süreye bağh alacakları mevcut veya müstakbel alacaklardan ayrı bir kategori içinde mütalaa etmek uygun olur.

(12) Wolff, sh. 209 vd; Fromer, sh. 277.

(13) Haenslex, sh. 37; Hahnzog, sh. 15.

(14) Haenslex, sh. 37 .

(15) bk. von Tuhr/Escher, sh. 254; Gauch/Schkuep, II, N. 2605.

(I6) Haensler, sh. 37-38.

(17) von Tahr/Escher, sh. 46; Gauch/Schluep II, N. 2675 vd; Engel, sh. 569; Merz, SPR VI/1, sh. 152-153; Eren, C. III, sh. 347-348.

(18) Haensler, sh. 3?, N. 12.

(19) Haensler, sh. 38, 39. 
Müstakbel alacaklarm temlik edilebilmesi, belirli olmaları halinde mümkündür.

\section{a) Belirlilik asast}

Federal Mahkemeye göre (20) müstakbel alacağın temlikinde, temlik edilecek alacağın, borçlunun şahsı, hukuki sebep ve miktar açısından belirli veya en azından belirlenebilir olması gerekir. Devredilen alacağın belirli olması esası doktrin tarafından da benimsenmiş bulunmaktadır (21).

Söz konusu belirlilik veya belirlenebilirlik şartı ne zaman gerçekleşmelidir? Bu soruya üç türlü cevap verilebilir: l) temlik sözleşmesinin gerçekleştiği an, 2) alacăğı doğduğu an ve 3) alacağın ileri sürüldüğü an.

Federal Mahkeme 12 mayıs 1987 tarihli kararinda yukardaki soruyu şu şekilde cevaplandırmaktadır (22): "müstakbel alacağın temlikinin geçerli olması için, alacağın doğduğu anda belirli; yani belirlenebilir olması yeterlidir. Gerçekten bu görüş tarzı, temlik edenin işletme veya ticari bir faaliyetinden doğan bütün müstakbel alacakları temlikinin geçerliliğini kabul ile băğdaşabilen yegâne görüştür; zira böyle bir durumda temlik edilen alacaklar, temlik sözleşmesinin kurulduğu anda (borçlunun şahș vs bakımından) mahiyeti icabı belirli değildir. Bundan başka, bu görüş tarzı, temlik anında ekserịya borç lusu ve miktarı bilinmeyen, ücretlerin temlikinin kabulü ile bağdaşabilen yegâne görüştür"

Yazarların büyük bir çoğunluğu (23) Federal Mahkeme tarafindan savunulan yukardaki görüß̧ tarzmı benimsemektedir..

(20) BGE 57 II 539. Federal Mahkemenin daha sonraki kararlarnda genellikle ayn ifadeler kullanılmak suretiylé bu karara atıf yapılmıştır: BGE 6I II 331 ; 75 III III; 82 II 48; 84 II 366; 85 I 30; 98 II 21; 90 II 179; 94 II 280; 95 III 12; 112 II 495 yahut JdT 1987 I 164; 112 II 243; 113 II 165.

(21) von Tuhr/Eschex, sh. 350; Guhl/Merz/Kummer, sh. 235; Zobl, Syst Teil, N. 1570; Walder, sh. 15; Amonn, Blatter, sh. 132; Ozer/Schrnemberger, Art. 164, N. 4; Becker, Art. 164, N. 15; Kaderli, sh. 110; Kramer, Allg Einleitung, N. 76; Oberlin sh. 101; Ganch/Schluep II N. 2179, 2199.

(22) . BGE I13 II $、 166$, cons. $2 b$.

(23) Zobl, Syst Teil, N. 1570; von Bïren, Allg Teil, sl. 325; Gahl/Merz/Kummer, sh. 235; Fromer, sl. 307; Jeanpretre, SJZ 1967, sh. 20; von Tuhr/Escher, sh. 350, dn. 75; Kleyling, sh. 76, dn, 40 a ait metin; Oberlin, sh. 10I. 
Buna karşllk, Bucher (24) ve Wiegand (25) doktrin ve Federal Mahkemenin geliştirmiş bulunduğu, yukarda zikredilen belirlilik kavramna itiraz etmektedir. Her iki yazara göre, temlik taahhüdü (pactum dc ccdendo) açısından, M.K m. 23/ II'deki sınırlar içinde kalınmak kaydıyla Federal Mahkeme ve diğer yazarlarca kabul cdilen belirlilik yeterlidlir; taahhüt muamelesinin kurulduğu anda daha fazla bir belirlilik istemeye gerek yoktur (26). Buna karş̧lık, gerçek anlamda temlik, yani tasarruf işlemi olarak temlikte alacağın doğduğu veya ileri sürüldüğü anda belirli olması yetmez; temlikin yapıldığı anda temlik konusu alacaklarm belirli olması gerekir. Kanunda genel bir biçimde düzenlenmemiş olmakla beraber, eşya hukukunda geçerli olan belirlilik (tahsis =spezialitaet) prensibi gereğince aynî haklar ancak belirli, muayyen bir eşya üzerinde kurulabilir; aynî hak durumunda. değişiklik meydana getirecek tasarruf işlemlerinin konusunun belirli, muayyen olması gerekir. Eşva hukukunda geçerli olan hukuki güvenlik ve aleniyet mülahazalarımın, alacaklar açısından fazla önemli olmadığı söylenemez (27). Binaenaleyl, belirlilik ilkesinin eşya hukuku dışında kalan diğer hakların intikalinde de, yani alacağın temlikinde de geçerli olması gerekir (28). Bunun tabii sonucu olarak, tasarruf işlcmi olan temlikin geçerliliği, bu işleme konu olan alacağın, temlik esnasında belirli olmasına bağhlıdır; alacağın doğduğu veya ileri sürüldüğü esnada belirli olması tasarrufi anlamdaki temlik için yeterli değildir (29). Bucher, Federal Mahkemenin son iki kararmu (BGE 112 II 435 ve 113 II 167) bu açıdan tenkid etmekte ve söz konusu kararların, alacağın temlikinde kanunun açıkca kabul ettiği taahhüt muamelesi-tasarruf muamelesi ayırımıyla bağdaşamayacağımı ileri sürmektedir (30). Bucher ile ayni görüşü bènimseyen Wiegand'a göre, ayırım yapmaksızın her türlü müstakbel alacağın temlik edilebileceğini kabul, sadece belirlilik ilkesine aykırı olmakla kalmaz; ayni za-

(24) Bucher, sh. $543 \mathrm{vd}$; ayni yazar, Kredisicherung, sl. 2 I ve recht 1989, sh. 1t vd.

(25) Wiegand, Kredisicherung und Rechtsdogmatik, sh. $288 \mathrm{vd}$; ayni yazar, 7.RJV 1980, sh, $361 \mathrm{vd}$.

(26) Bucher, sh 543-544; ayni yazar, recht 1989, sl. 14.

(27) Bucher, sh. 544 vi dn. 31 .

(28) Wiegand, Kredisicherung und Rechtsctogmatik, sl. 289. Wiegand, Bucher,'in eşya lnukuku işlemlerinde geçerli olan belirlilik ịlkesini temlike rakleımesini hukuk politikası bakımından doğru butmakla beraber, bilimsel asıdan lizulj addetmektedir. Ona göre belirlilik ilkesi tasarrul kavramina zorunlu olarak bağlt w hatta onun. la vücut bulmuş bir ilkedir (Kredisicherung und Rechisdogmatik, sh. 299, sln. 23 j.

(29) Bucher, slt. 544, dn. 32'ye ait metin.

(30) Bucher, slt, 544, dn. 33 ve.34'e ait metinler; Wiegand, ZBJV 1980, sh. 563. 
manda alacağın temlikinin geçerliliğini yazılı şekilde yapılmasına bağlı kılan BK m. 163/I hükmüyle de çelişmektedir. Zira bu hükmün amacı tıpkı MK 690'da olduğu gibi, üçüncü kişileri korumaktır. $\mathrm{Bu}$ husus, 1881 tarihli borçlar kanununun I84. maddesinde yer alan, temlikin taraflar arasında şekilsiz, üçüncü kişiler bakımından yazılı olarak tes sikini öngören hükmün BK $163 /$ I ile terkedilmesinden de anlaşılır (31). Engel'in de Federal Mahkemede görülen davada kullanılan hukuki mütalaasında ayni görüşü savunduğu görülmektedir (32).

Federal Mahkemeye göre, "şüphesiz teorik değerden yoksun bulunmayan bu görüş (Bucher ve Wiegand'in görüşï), mahkeme içtihatları ve doktrine istinaden, en azından doğduğu anda belirlenebilir alacakların temlikin̄in geçerlilĭgini kabul eden, kredi konusunda inkişaf etmiş bulunan (bk. Zobl, op cit, N. 1673 vd) topyekûn temlik uygulamasıyla uyuşmamaktadır. Temlik işleminin, doğduğu anda alacă̆ın belirlenmesine imkân veren unsurlarm tamamın: ihtiva etmesi gerekir; fakat bir defa bu şart gerçekleştił̧inde bir tasarruf işlemine veya sonraki belirlemeye gerek yoktur. Genel bir ifadeyle, esaslı unsurlarından biri işlemde belirlenmemiş olsa bile, alacağın temliki şekil bakımından geçerlidir. Elverir ki, gerektiğinde üçüncü şahıslardan sâdır olan sonraki beyanlar sonucu olsa dahi (BGE 85 II 52), yeterince belirlenmiş olsun; bunun için, doğduğu zaman alacağı kesinlikle belirleyen yeni bir yazlh işleme (belgeye) de gerek yoktur. Eşya hukukunda mevcut şekliyle, özellikle orada uygulanan alenîlik kuralıyla bağlantılı olarak (gayrimenkul rehni için tapu siciline tescil, MK m. 771; menkul rehni için teslim, MK 853), borçlar hukukunda doğrudan dogruya uygulanamaz. Esasen belirlilik (tahsis = specialité) prensibi, eşya hukuku alanı̣nda dahi,rehin değil, onun garanti ettiği alacak söz konusu olduğu zaman sıkı bir şekilde uygulanmamaktadir (Zobl, op. Cit. N. 267, BGE 108 II 47)' (33).

Bazı yazarlar (34), Federal Mahkemenin sözụnü ettiği uygulamanın örf ve âdet (gelenek) hukukuna dayandığını; örf ve âdet kurallarının niteliklerinden olan uzun süreden beri uygulanma ve opinio necessitus veya opinio juris unsurlarının olayda gerçekleştiğini

(31) Wiegand, Kredisicherung und Rechtsdogmatik, sh: 292 vd.

(32) BGE 113 II 164 .

(33) BGE 113 II 167.

(34) Zobl, Syst Teil, N. 1673; Oberlin, sh. 117 vd; Federal Mahkemenin 8.9.1977 t2rikii neşredilmemiş kararı (Nobel, sh. 358 vd). 
ifade etmekteler. Böylece, preter legem, kanun yanında boşluğun örf ve âdet kurahyla doldurulduğu görüşü kabul edilmektedir. Federal Mahkemenin anıla kararında bu husus açıkca ifade edilmemiş olmakla beraber, Zobl'a yapilan yollama(Syst Teil, N. 1673)ve kararın bütünü dikkate alındığında Isviçre yüksek mahkemesinin de bu fikri benimsedị̌i söylenebilir $(35,36)$.

Müstakbel alacakların temliki konusunda ileri sürülen biribirinden farkh bu iki görüs hakkında sağlıklı bir değerlendirme yapabilmek için, eşya hukukuna hâkim olan prensiplerin alacağın temlikine uygulanı uygulanamayacağı meselesi ile alacağın temlikinin bir tasarruf işlemi olmasına atfedilen sonuçları yakmdan incelemek gerekir.

b) Essa Hukukuna hâkim olan belirlitik (tahsis) ve aleniyet prensipleri

aa) Belirlilik (tahsis) prensibi (Spezialitaetsprinzip)

Bura göre ayni haklar, ancak münferit, ferdileştirilmiş ve belirli bir eşya veya hak üzerinde kurulabilir (37). Eşya topluluğu (Sachgesamtheiten) ve hukuki tümlükler (Rechtsgesamtheiten) ancak borçlar hukuku işlemlerine konu teşkil edebilir (38).

bb) Aleniyet prensibi (Publizitaetsprinzip)

Aleniyyet prensibi, bir eşya üzerindeki aynî hakkın üçüncü şahıslar tarafindan kolaylıkla anlaşılabilecek tarzda gözükmesidir. Buna göre, ayni hakların kurulması, devri ve ortadan kalkmasının üçüncü şahıslar tarafindan kolaylkkla anlaşılabilecek bir biçimde gerçekleşmesi gerekeir (39). Ayní haklar herkese karş̧ı ileri sürülebilen mutlak haklardandır. Ayni hakları ihlal etmemekle yükümlü olan üçüncü

(35) Klein, (sh. 214, olayların ağırlı̌̆ı altunda kanun boşluğu dolduran bir kuralın varìgin Federal Mahkeme kabul etmektemidir? sorusunun sorulacagłın ifade etmektedir. Ancak, yazar'ın bu soruya açık bir cevap vermediö gözlenmektedir.

(36) Merz'in BGE I13 II 163'de yaynlanan Federal Mahkeme kararını tahlil eden yazıstmu sonunda (ZBJV 125/1989, sh. 214) su ifadeler yer almaktadir: "lederal Mahkemenin temsil ettigi görüşün, inançl topyekun temlikin teminat alkma aldığ̊ alacakların teminatsız alacaklara tekaddüm ettiği sonucuna varmast isabetlidir. Bu her zaman olmasa bile, münferit olayda hakkaniyete uymayan sonuçlan mucip olabilir; fakat esas itibariyle caiz bit temele dayanan imityazlandırma vardar. Bu durum esas itibariyle genel olarak hakkaniyete aykn mütalaa edilecekse, kanun koyıcu tarafindan bertaraf edilmelidir".

(37) Meier-Hayoz, Syst Teil, N. 34, 78; Zobi, Syst Teil, N. 257; Akipek, C.I, sh. 125 Oguzman/Seliçi, sh. 22; Unal, sl. 40; Haenslex, sh. 59; Oberlin, sh. 105-106.

(38) Meier-Hayoz, Syst Teil, N. 34, 84; Zobl, Syst Teil, N. 257; Oberlin. sh. 106. 
şahıslar, aleniyet prensibi sayesinde ayni hakların varlı̆̆ını ve sahibinin kim olduğunu öğrenebilirler (40).

Medeni Kanun, aleniyyet vasitasi olarak menkullerde zilyetliği (MK m. 687), gayrimenkullerde tapu sicilini öngörmüş ve bunlara hak sahipliği karinesi bağlamıştır (MK m. 899 ve 905) (41). Bunun sonucu olarak, ayni haklar, ona aleniyet kazandıracak vasitalara başvurmaksızın kazanılamaz ve kurulamaz (42).

Aleniyyet prensibi hukuki işlemlerde şeffaflığ ve açıklı̆ğ sağlar; bu sayede hukuki emniyet sağlanmış olur. Bu açıdan aleniyyet prensibi ile belirlilik prensibi arasında yakin bir bağ mevcuttur (43).Menkul rehninde hükmen teslim yasağı bu amaçla öngörülmüştür (MK m. 853) (44). Başka bir ifadeỵle, belirlilik prensibi; aleniyyet prensibinin gerçekleşmesini sağlayan bir araçtır. Eşyaların münferiden tasarruf işlemine konu olması zarureti, aleniyet prensibinin getirdiŏgi şartların ortadan kalkmasını önler; belirlilik prensibinin varlık sebebi, aleniyyet ilkesini gerçekleştirmektir (45).

Bucher ve Wiegand, belirlilik ilkesinin alacağın temlikine de uygulanacă̆ına ilişkin görüşlerini, alacă̆ın temlikinin bir tasarruf işlemi olduğu gerekçesine dayandırmaktadır (46). Az önce de ifade edildiği gibi, eşya hukukundaki belirlilik ve aleniyyet ilkeleri, ayni hakların herkese karşı ileri sürülebilen mutlak hakJardan olması sebebiyle kabul edilmiştir (47). Bu ilkelerin nisbi nitelik taşıyan, yani sadece borçluya karşı ileri sürülebilen, alacak haklarina aynen uygulanması, onlarm konulus amacına uygun düşmez (48). Nitekim Bucher (49)'in görüşünü savunurken kendisine yollamada bulunduğu MeierHayoz, eşya hukukundaki belirlilik prensibini, aleniyyet ilkesinden çıartmakta ve onu genel anlamda tasarruf işleminin sonucu telakki etmeyip, ayni hakların mutlak hak olması özelliği ile izah etmekte-

(39) Akipek, C.I, sh. 124; Meier-Hayoz, Syst Teil, N. 22.

(40) Meier-Hayoz, Syst Teil, N. 22; Zobl, Syst Teil, N. 272; Haab, Einleitung, N. 62; Ołuzman/Seligi, sh. 23; Unal, sh. 41.

(41) Meier-Hayoz, Syst Teil, N. 23, 24; Haenelex, sh. 61; Haab, Einleitung, N. 63; Unal, sh. 42; Oguzman-Seliçi, sh. 23-24; Zobl, Syst Teil, N. 273, 274.

(42) Unal, sh. 42; Fleneler, sh. 61. MK m. 892, bu hususta bir istisna teqkil eder.

(43) Haensler, sh. 59, N. 4, sh. 67, N. 19; Oberlin, sh. 110.

(44) Oberlin, sh. 110.

(45) Haensler, sh. 19.

(46) Bucher, sh. 544; Wiegand, Kredisicherung und Rechtsdogmatik, sh. 289; ayni yazar, ZJBV 1980, sh. 563 .

(47) bk. yuk. 3, 6

(48) Hangler, sh. 68, N. 22.

(49) Bucher, sh. 544, dn. 31. 
dir (50). Ayni şekilde, eşya hukukunda aleniyct prensibinc bağlanan mülkiyet karinesi (MK m. 898 ve 905) ve bu prensibin sonucu olan iyiniyetin korunması esası (MK m. 901, 903, 906, 939 ve 931) alacağın temlikinde söz konusu değildir. BK m. 169 hükmü bu hususu teyid eder. Nisbi haklarda iyiniyetin korunması kuralının iki istisnası BK m. 18/II ve 162/II'de düzenlenmiștir. Bu iki kural, kanunda tüketici bir biçimde düzenlenmiş olup, diğer hallere teşmil edilemez (51).

Wiegand'a göre (52), alacağın temlikinin geçerliliğini yazılı şekilde yapılması şartına bağlayan BK m. 163/I hükmü, üçüncü şahısları koruma amacryla konulmuştur. Bu hükümde öngörülen yażlı şckil, alacağın temlikine aleniyyet sağlar. Böylece üçüncü şahıslar tasarruf işleminin yapıldı̆̆ ${ }_{1}$ anda, temlik edilen alacağı teşhis ctme imkânı elde ederler.

Bu hususta isabetli bir sonuca varabilmek için, BK m. 163/I'deki normun koruma amacmı tesbit etmek gerekir. 1881 tarilıli İsviçrc borçlar kanununun BK m. 163/I'e tekabül eden 184. maddesinde, "alacağın temliki özel bir şekle tabi olmaksızın bağlayıcıdır. Fakat üçüncü şahıslara karşı, özellikje temlik edenin iflâsında temlikin gêçerlililiği için yazılı şekilde belgelenmesi gereklidir" denilmektedir. Isviçre Borçlar kanununun hazırlık komisyonunda almanca raportör Eugen Huber, BK 163/I ile yapılan değiş̧iklikle, temlik sözleşmesinin hükümlerinin gerek taraflar, gerek üçüncü şahıslar bakımından ayni duruma getirildiğini ifadeyle yetinmektedir (53). Buna göre kanunun hazırlık çalı̧̧malarından yazılı şeklin aleniyyet sağlamak amacıyla konulduğu sorucunu çıkarmak mümkün olmamaktadı (54).

BK m. 163/I'in objektif teleolojik yorumundan ne gibi sonuç ç1kartılabilir?

BK m. 163/I'deki şekil mecburiyetinin amacı, temlik cdeni acele kararlara karşı korumak değildir. Zira kanun koyucunun amacı bu olsaydı, temlik taahhüdü için de yazılı şekil öngörülürdü. Oysa kanuı koyucu temlik taahüdünü berhangi bir şekil şartına bağlamamıştır (55).

(50) Meier-Hayoz, Syst Teil, N. 34: "Dingliche Rechic enstehen dagegen inmer nus an dejenigen einzelnen Sachen an denen die erfordlichen Publizitietsiormen crlüllt werden sind". Ayrica bk. Haensler, sh. 70, N. 4.

(51) Haensler, sh. 75, N. 17; von Tuhr/Peter, sh. 180, dn. 60 ve buna ait metin; von Tuhr/Escher, sh. 332, dn. 22 ye ait metin. Koller, BK m. 165 ve 167 'yi borclunun iyjniyetini koruyan hüküm olarak nitelenmektedir, sh. 187-189, ․ 592-.593.

(52) Wiegand, Kredisicherung und Rechtsdogmatik, sh. 292 vct.

(53) bk. Sten Bull (NR) 21 Ekim 1909, sh. 555.

(54) Haensler, sh. 73, N. 12.

(55) von Tuhr/Escher, sh. 334-335; Becker, Art. 165, N. 2; Haensler, sl. 73-74, N, 14; Oser/Schönenberger, Art. 165, N. 3. 
BK. m. 163/I'de öngörülen şekil şartının amacı temlik edilen alacağın borçlusunu temlik veya birbirini takip eden müteakip temliklerden haberdar etmek ve alacaklıya temlik edilen alacağın borçlusuna karşı hak sabibi olduğunu belgelemek imkânı vermektiı (56). Bina enaleyh, yaztl şekilde yaplan temlik sözleşmesine, eşya hukukunda tapu sicii ${ }^{i}$ ve zilyetlikte olduğu gibi, aleniyyet fonksiyonu izáfe etmek mümkün değ ldir. Alacağı devıedenle devralan arașında kuıulan ve herhangi bir sicile kaỵ̂t edilmesi gerekmeyen temlik sözleşmesinden üçüncü şahısların bilgi edinmesinden söz edilemez (57). Buna göre, eşya hukukundaki belirlilik ve aleniyyet prensibini alacağın temlikinde uygulamak mümkün olmadığı gibi, bu konuda bir zaruret de bulunmamaktadır. (58).

Diğger taraftan, Wiegand, von Tuhr'un BK m. 163/I'e eşya hukuku anlamında aléniyet sağlayan bir hüküm niteliuği verdiğini iddia etmektedir (59). von Tuhr'un kullandığı, "temlik şeklinin 'anlam,, diğer hallerde mezela kefalette olduğu gibi, temlik edeni acele kararlara karşı korumak olmavıp (zira BK m.163/II geregunce temlik şekilsiz olarak taahhüt edilebilir), bilakis, temlik olayın üçüncü şahısm lar, özellikle borçlu için kolayca öğrenilebilir kılmaktır" ibaresinden (60) böyle bir sonuç çlkartılamaz (61).

Kanaatimizce, topyekûn temlikte belirlilik bakımından, alacağın doğduğu anda belirli olmasını yeterli sayan hâkim görüşe üstünlük tanımak gerekir. Ileri sürülme tarihinin keyfiliğe yol açmassı mümkündür.

(56) Haensler, sh. 74, N, 15; Zobl, Syst Teil, N. 1686; ayni yazar, SJZ 1989, sh. 352, dn. 40; Staehelin, sh. 384; Oberlin, sh. 114; Oser/Schbnenberger, Art. 165, N.3.

(57) Zobl, SJZ 1989, sh. 353, dn. 44; Homburger, SAG 1988, sh. 158; Merz, ZBJV 1989 sh. 213, 214. Wiegand'ın görüşüne mütemayil olan Klein da, "š̈phesiz bu sistemin zayıf tarafları var ve, onun sağladı̆̆ aleniyet tam değildir" demek suretiyle bu hususu itiraf etmektedir (Klein, sh. 217).

(58) Stahehelin'e göre (sh. 384), "alacak mevcưt olmadığı sürece, ne hukuki açıllık, ne hukuki güvenlik ilkeleri alacağın tüm esasłı noktalarıyla belirli olmasın isteyemez".

(59) Wiegand, Kredisicherung und Rechtsdoğmatik, sh. 293.

(60) von Tuhr/Escher, sh. 335, dn. 48'e ait metin.

(6!) Nitekim, Wiegand bir yil sonra yazdtŏ baska bir makalesinde, ZBJV 1980 sh. 564, BK. m. 163/I e ilişkin olarak, ". . esasen üçincü şahıslara karşı önceden haber ver. me değil, her şeyden önce isbat edilebilirlik söz konusudur" demektedir. Haensler, sh. 72 , dn. 18 . 


\section{§ 4. MÜSTAKBEL ALACAKLARIN TEMLIKININ HU. KUKI NITELIGI}

Yukarda da ifade edildiği gibi (1), alacağın temliki bir tasarruf işlemidir. Tasarruf işlemleri, bir hakkı veya hukuki ilişkiyi doğrudan doğruya etkileyen, onu diğer tarafa geçiren, muhtevasın sınırlayan, değiş̧tiren veya ortadan kaldıran işlemlerdir (2). Bu işlemlerin yapılmasıyla, işleme konu olan hak, başka bir irade açıklamasına gerek olmadan, tasarruf işlemini yapanın mamelekinden çıkıp, diğer tarafin mamelekine girer. Ayni şekilde alacağın temliki işleminin yapıl* masıyla, alacak, temellük edenin mamelekine dahil olur (3).

Bu durum karşısında, henüz doğmamıs müstakbel alacakların devriyle, tasarruf işleminin hak üzerindeki doğrudan etkisini nasıl izah etmek gerekir?

Tasarruf işlemlerinde, normal olarak, işlemin yapıldı̆̆ı anda üzerinde tasarruf edilen hakk'n doğumu için gerekli şartlar (Tatbestandselemente) mevcuttur. Bununla beraber, müstakbel alacaklara, şarta veya süreye bağlı alacaklara iliş̧kin tasarruflarla üçüncü şahısların icazetine ihtiyaç gösteren tasarruflarda bu kuralın istisnası söz konusudur (4). Bu istisnai durumlarda, bip önceden tasarrufun (Vorausverfüngen) varlığı kabul edilmektedir.

Tasarruf işlemlerinde, işlemin yapıldığ 1 an ile tasarrufun hukuki sonuçlarını doğurduğu anı birbirinden ayırmak gerekir (5). Tasarruf işlemlerinde, bu iki anın birlikte bulunması zorunlu değildir. Bu itibarla, önceden tasarruf hallerinde, tasarruf işlemi hukuki sonuçlarını alacağın doğduğu anda gerçekleştirir (6). Bununla, tasarruf işleminin hukuki durumda doğrudan doğruya değişiklik yapma olgusu bertaraf edilmiş olmamaktadır. Buraḍa geçen doğrudan doğruya deyimini, zamana ilişkin olarak anlamamak gerekir; bu deyimden, hukuki değişikliğin başka bir irade açıklamasına veya hukuki fiile ihtiyaç ofmaksızın gerçekleşmesi anlaşılır (7).

(1) bk. yukarda \$I, II, 2.

(2) von Tuhr/Peter, sh. 194; Engel, sh. 111; Bucher, sh. 42 vd; Keller/Schöbi, I, sh. 12 ; Eren, C. I, sh. 231.

(3) bk. yukarda $\$ 1, \mathrm{II}, 2, \mathrm{dn} .7$ ve buna ait metin.

(4) bk. Fromer, sh. 286-287; Haensler, sh. 43.

(5) Fromer, sh. 286; Haensler, sh. 52, 54, 55.

(6) Fromer, sh. 286-287, 292; Haeriler, sh. 52 vd.

(7) Fromer, sh. 286-287, 292; Haensler, sh. 52, 26; Hahnzog, sl. 23, 25; von Tuhr/ Escher, sh. 349; RGZ 67, 167. Ayrica bk. Zobl, Syst Teil N. 674; Obexlin, sh. 113. 
Isviçre-Türk hukukunda müstakbel alacakların devredilebilirliği âdi şirkette ortakların kâr payı ve tasfiye payını düzenleyen $\mathrm{BK}$ m. $523 / \mathrm{I}$ ve $\mathrm{m}$. 539/I hükmlerinden dolaylt olarak çkartılabilir (8). Kâr payına ilişkin talep ancak faaliyet yılının sonunda doğar; tasfiye payı ise, şirketin infisahı veya bir ortağın şirketten ayrılmasıyla doğar. Bu olguların gerçekleşmesinden önce âdi şirkete hâkim olann elbirliği prensibi sebebiyle ortaklar için mevcut bir alacak sözkonusu değildir. Bu müstakbel alacakların devredilebileceği kanunda açıkca hükme bağlanmamı̧ ise de, doktrin ve uygulamada genellikle kabul edilmektedir (9).

Ayni şekilde, müstakbel alacakların devredilebilirliği $\mathrm{MK}$ m. 778'den de çıkartılabilir. Bu maddenin II. fıkrası hükmüne göre, rehnedilen gayri menkulün malikinin, henüz muaccel olmamış kira alacakları üzerinde yapacağı hukuki tarsarruflar, alacă̆ı gayrimenkul rehniyle temin edilmiş alacaklıya karşı geçerli değildir. Burada geçen tasarruf kavramma, bir tasarruf işlemi olan temlik dahildir. MK m. 778/II hükmünden, zit kavram (argumentum e contrario) yoluyle, müstakbel kira alacaklarinm önceden temlikinin, gayri menkul rehniyle temin edilmiş alacağın alacaklısının dışındaki şahıslara karşı geçerli olduğu sonucu çıkartılabilir (10).

Aynî haklar üzerinde önceden tasaı ruf mümkün mü?

Eşya hukukunda mülkiyetin kazanılması için gayrimenkullerde tapu siciline tescil (MK m. 633/ I, c. 1), menkullerde teslim (zilyetliğgin nakli) (MK m. 687) şarttır. Tapu kütüğüne ancak mevcut haklar tescil edilebileceği için, gayri menkuller üzerinde önceden tasarruf mümkün değildir. Menkullerde mülkiyetin kazanılması için, zilyetliğ in nakli kurucu unsurdur. Bununla beraber, doktrinde; $\mathrm{MK} \mathrm{m}$. 892 / I gereğince hükmen teslim yoluyla zilyetliğin devrinde, zilýetliği devreden kişinin henüz mah iktisab etmedił̆i bir zamanda, hükmen teslim anlaşmașın yapabileceği ve bu anlaşmanın hükümlerini zilyetliği nakledecek kişinin malı elde ettiği anda doğuracağı kabul edilmektedir (11). Bu tür hükmen teslime, önceden hükmen teslim

(8) Fromer, sh. 256.

(9) Fromer, sh. 296 ve dn. 66 ve 67 de zikredilenler.

(10) Fromer, sh. 297.

(11) Homberger, Zürcher Kommentar, Bd. VI/5, Besitz und Grundbuch, Bern 1938, Art. 924, n. 12; Hinderling, SPR V/1, sh. 436; Stark, Berner Kommentar, Bd. IV/3/1, der Besitz, Bern, 1984, Art. 924, N. 46; Haab/Scherrer, Art. 717, N. $33^{\circ}$ vd; Oguzman,/Seligi, -sh. 77, dn. 68a; Seroxan (Hatemi/Arpaci), Esya Hùkuku, İstanbul 1991, sh. 309. 
(antezipierten oder antezipierenden Besitzeskonstitut) adı verilmektedir. Ancak MK m. 690 hükmü, önceden hükmen teslin yolunun uygulanmasını önemli ölçüde sınırlandırmış bulunınaktadır (12).

Gayrimenkul üzerindeki irtifak hakları ve gayrimenkul mükellefiyetleri üzerinde önceden tasarruf mümkün değildir. Zira bunların kazanılması için tapu kütüğüne tescil kurucu nitelik taşı 704 ve 755$)(13)$.

Menkuller üzerinde kurulacak intifa haklarının önceden trsatruf işlemine konu olması hususunda, menkul mülkiyeti üzerinde önceden tasarrufla ilgili olarak söylenenler geçerlidir. Ayrıca MK m. 718 gereğince menkuller üzerinde intifa hakkmın kurulabilmesi için, menkulün intifa hakkı sahibine teslimi, onun vasitasız zilyet kılınması şarttır (14). Buna karşılık, alacak üzerinde kurulacak ir tifa hakkına iliskkin önceden tasarruf mümkündür (15).

(12) Haensler, sh, 46, N. 11.

(13) Haensler, sh. 46, N. 12.

(14) Oguzman/Seliçi, sh. 724-72s.

(15) Haensler, sł, 45 vd, özellikle, sh. 49, N. 16. 


\section{§5. BORÇLULAR LISTESININ GÖNDERILMESININ HUKUKI NITELIĞ}

Topyekûn temlik, yeni doğan alacakların devamlı olarak temlik kapsamına girmesini ve ayni zamanda temlik borçlusu tarafindan ödenen alacaklarin sona ermesini tazammun eder. Bu durum, topyekun temlik çerçevesinde alacağı devralanın münferit alacaklar hakkında doğru bilgilere sahip olması zaruretini doğurmaktadır (1). Yukarda da ifade edildiği üzere (2) isviçredeki uygulamada, Isviçre Bankalar Birliği 2.6.1989 tarih ve 224 numaralı gebelgesindeki tavsiyelere uygun olarak, bankalar, temlik edenden belirli araltklarla ayrnntlı alacak listelerinin gönderilmesini ve o andaki alacaklar durumunun bildirilmesini temlik sözleşmesine bir şart olarak dercetmekteler (3). Böylece, taraflar, topyekün temlik ile temellük edene geçen alacakları, doğar doğmaz teşhise edebilme imkânına sahip olurlar. Bu teşhis keyfiyeti tomlik edenin her mal veya hizmet edimi mukabilinde aldığ faturanın bir suretiní temellük edene göndermesiyle basit ve ihtilafsız bir şekilde gerçekleşir (4). İsviçre uygulamasında, her ay temlik edenin alacaklarının toplam mevcudunu ve üç ayda bir ayruntlı alacaklilar listesi gönderilmesi mutaddır (5). Ayruntılı listeler, devralana BK m. 165 uyarmca temlik borçlusuna ihtarda bulunma imkânı sağlar. Bununla beraber, temlik borçlusunun, temlik edenin talimatı üzerine borcunu temellük edene ödemesi balinde de, topyekûn temlikte aleniyet sağlanmış olur (6).

Yukarda belirtilen şekilde, borçlular listesi gönderilmesinin hukuki niteliği konusunda farkh görüşler ileri sürülmektedir.

Bucher'e göre (7) borçlular listesinin gönderilmesi bir tasarruf işlemi niteliği taşı ve ayni zamanda kurucu niłelikte belirlilik sağlayan işlem hüviyeti arzeder. Bu görüş topyekùn temliki bir taahhüt işlemi, bir çerçeve temlik (Mantelzession) saymanın tabii bir sonucudur.

(1) Oberlin, sl. 102 .

(2) bk. yuk. $\$ 2$, II

(3) Oberlin, sh. 48-49, 102; Albisetti/Boemle/Ehrsam/Gsell/Rutschi, sh. 337338 ; Zobl, Syst Teill, N. 1687.

(4) Amonn, Blatter, sh. 134-135.

(5) Amonn, Blatter, sh. 135; Oberlin, sh. 103; Gubl/Merz/Kummer, sh. 235.

(6) Amonn, Blatter, sh. 135.

(7) Bucher, sh. 454 vd, özellikje dn. 31; ayni yazar, recht 1999, sh. 15. 
Başka bir fikre göre (8) borçlular listesinin gönderilmesi, bildirici bir nitelik taşır. Bununla beraber, topyekûn temlikle teminat altına alınan krediyi açan bankanin, borçlular listesinin gönderilmesini istemekten imtina etmesi, zımnen topyekûn temlikin kaldırıldığı sonucunu doğurabilir. Bu görüş̧e katılmak mümkün değildir. Zira bił tasarruf işlemi olan temlik sözleşmesiyle alacaklı değişikliği gerçekleşmiştir. Bunun tekrar bozulabilmesi için yeni bir temlik işlemine (Rückzession) ihtiyaç vardır; bu da BK m. 163/I gereğince ancak yazılı bir şekilde yapılabilir. İsviçre-Türk hukukunda ibranın şekle bağlı olmaması. (OR 115) (9) sonucu değiştirmez. Cü̈nkü, topyekûn tenlik alacaklı słfatını değiştirdiği için, ibra temellük edenle temlik borçlusu arasında söz konusu olabilir (10).

Buna karşllkk bizim de katıldığımız diğer bir fikre göre (11); borçlular listesinin gönderilmesi sade,ce bilidirici nitelik taşır; bununla önceden yapılan temıik somut olarak teyid edilmiş olur. Borçlular listesinin gönderilmesinin pratik anlamı, temellük edeı, özellikle temkredisi açan bankalara temliki kontrol etmek ve gerektiğinde temlik borçlusuna ihbar etme imkânı sağlamaktan ibarettir.

(8) Guhl/Merz/Kummer, sh. 235; Albisetti/Boemle/Ehrsam/Gsell/Nyffeler/ Rutschi sh. 338; Amonn, Blatter, sh. 135.

(9) Zobl, Syst Teil, N. 1687; ayni yazar SJZ 1989, sh. 355-356; Haensler, sh, 96, N. 31; von Tuhr/Escher, sh. 338; Oberlin, sh. 102; Bergmaier, sh. 172, 179; BGE 105 II 268, Erw.2a.

(10) Haensler, sh. 96-97, N. 31; Zobl, Syst Teil, N. 1687; ayni yazar, SJZ 1989, sl. 356; Oberlin, sh. 102.

(11) Zobl, Syst Teil, N. 1687; ayni yazar, SJZ 1989, sh. 356; Haensler, sh. 97, N. 32; Oberlin, sh. 102-103; Schönle, sh. 148. Nobel, sh. 360'da zikredilen 8.8.1977 tarihli yayımlanmamış Federal Mahkeme kararı; BGE 113 II 168, cons. 2d. Federal Mahkeme alacak rehıni konusunda da ayni esası benimsemiştir: BGE 69 II 294, cons.2b. 


\section{§ 6. TOPYEKUN TEMLIKIN SINIRI: MK m. 23/II}

\section{I- Genel Olarak MK m. 23/II'nin anlamı}

Isviçre-Türk özel hukukunda temel kural fertlerin özgürlüğüudür. Hukuk düzeni, şahısları sorumlu ve kendi geleceğini tayine muktedir hukuk süjesi olarak telakki eder (1). Bunun sonucu olarak BK m. 19'da akit serbestisi jlkesi öngörülmüştür. Bu hüküm gereğince şahıslar, başkalarıyla akit yapmak, aktin tarafını seçmek ve aktin muhtevasun belirlemek hususlarında serbestce karar verme hak ve özgürlüğgune sahiptirler (2).

Ancak her özgürlük gibi, akit yapma özgürlüğünün de bir sınırı vardır. Nitekim bu sunılar BK $\mathrm{m}$. 19/II v 20/I de düzenlenmiş bulunmaktadır (3). Ayni şekilde, MK m. 23/ Il'de " $k$ 'mse, hürriyetlerini ferağ edemediği gibi kanuna ve adabı umumiyeye mugavir bir surette takyid dahi edemez", ifadesi yer alır. Bu sonuncu hükümle, kanun koyucu, şahıların hürriyetlerine getirilecek kayıtlarda uyulması gereken sınırı belirlemiştir. Şahıslar bu sınır çerçevesinde özgürlüklerine bir takyid getirebilirler. Bu kayıt ve sınırlamalar kaxar verme serbestisinin özüyle ilgili olmayıp, onun münferit bir veçhesine ilişkindir. Nitekim karar verme özgürlüŭüu çerçevesinde yapılan her karşılıklı borç yükleyen sözleşme, zorunlu olarak, üstlenilen borç sebebiyle kişilerin özgürlüğ̈üü sinırlar (4). Elverir ki, bu kayıt ve sınırlama münhasıran dışardan gelen bir baskının sonucu olmasın (5). Başka bir ifadeyle MK 23/II, sadece karar verme hürriyetinin kanun ve ahlaka aykırı derecede sinırlandırılmasını yasaklamaktadır (6).

Isviçre Medeni Kanununun, MK m. 23/II ye tekabül eden 27. maddesinin kenar başliğı 1983 yılında yapılan bir değişiklikle "aşırı ölçüde sınırlama". şeklinde değiştirilmiştir.

MK m. 23/II hükmü, bir açık norm niteliği (Blankettnorm) arzetmektedir. Bunun muhtevasınm somut olarak belirlenmesi, münferit olaylara göre yaptlacak yorumlarla mümkün olur (7).

(1) Grossen, sh: 11; Pedrazzini/Oberholzer, sh. 115.

(2) Pedrazzini/Oberholzer, sh. 115; Oberlin, sh. 124.

(3) Eren, Borçlar Hukuku, C.I, sh. 364.

(4) Pedrazzini, /Oberholzer, sh. 119; Oberlin, sh. 124; Haensler, sh. 101, N. 2; Egger, Art. 27, N. 35.

(5) Grousen, sh. 12.

(6) Pedrazzini/Oberholzer, sb. 119-120.

(7) Pedrazzini, Oberholzex sh. 120; Heansler, sh. 101-102, N. 2. 
Karar verme serbestisinin hukuki işlem yoluyla smurlandırılması, borç altına giren şahsı diğer şahsın keyfine tabi kıldığı ve özcllikle onun iktisadi varlığını tehlikeye düşürdüğü takdirde $\mathrm{MK} \mathrm{m}$. 23/ II anlaminda kanuna ve ahlâka aykırı saylmaktadır (8). MK m. 23/II hükmü, bir şahsın iktisadi gücünü aşan taahhtütter altına girmesini yasaklamaktadır. Bir sözleşmenin ahlâka aykırı olup olmadığı, borçlarım ifa için borçlunun sahip olduğu vasıtalara göre değil, sözleşmenin multevasina göre belirlenir (9).

Isviçre Federal Mahkemesine göre (10), "Medeni Kanunun 23. maddesinin (İsviçre MK m. 27) koruyucu hükmü özcllikle iktisadi faaliyetlere uygulanır. Akit serbestisinin suntrandırlması söz konusu olan hallerde, Federal mahkeme MK m. 23'e aykırılığı ancak ihtiyatla kabul etmektedir. Ferdi rekabet imkânının sinırlandırılması, ancak aşırı olduğu takdirde zikredilen hükmï ihlâl eder. Bunun vâki olup olmadığ́ müşahhas durumlara göre hükmedilir. Kural olarak, iktisadi hareket serbestisinin bir sözleşme veya statii gereği sınırlandırılması, ancak borç altına gireni diğer tarafın keyfine terkettiği, onun iktisadi hürriyetini kaldırdığı veya iktisadi varlığının temellerini tehlikeye düşürecek derecede sınırladığı takdirde, aşırı ölçüude sayılır (Egger, Art. 27, N. 35). Federal Mahkeme mükerreren bu anlamda karar vermiştir. BGE 95 II 57/58'de, borç altına girenin iktisadi varlığımı tehlikeye sokmuyorsa, karar verme hürriyetinin tahdit veya terki $\mathrm{MK} \mathrm{m}$. 23/II yi ihlâl etmez; MK m. 23/ II şahsi hürriyeti çok geniş, ahlâkat aykırı akdi müdahalelere karşı korumayı amaçlamakla beraber, akdi bağlılıklaı in hangi ölçüde caiz olduğunu belirtmemektedir, ifadesi kullanılmıştır. BGE 84 II 23 'de, iktisadi hürriyetin bir kısmını sözleşmeyle terkeden kimse, bununla iktisadi varhğın tehlikeye sokmuşsa, ahlâka aykırılığın varlı̆̆ kabul edilmiştir. BGE 51 II 168 'de şu satırlar okunabilir: Bu günkü iş hayatında şahsi hürriyetin şahși ve iktisadi açıdan geniş ölçüde kısıtlandığı, özellikle âkitlerin karş̣ılıkı menfaatlerinin birbirlerine bağlandığ vakidir ki, bunlar ahlâka aykırı sayılmaz; bu husus bağ lılı̆̆n tecriz edilen ölçüyü açıp aşmadığına ve borç altına girenin hürriyetini kullanırken onu, MK m. 23/ II anlamında ahlak hissini ihlal edecek derecede sımırlayıp sımırlamadığına bağlıdır; iktisadi şahsiyetin sınırlandırılması, borçlunun iktisadi

\footnotetext{
(8) Pedrazzini/Oberholzer, sh. 123; Grossen, sh. 12; Oberlin, sh. 125; BCEL I0? II $218 ; 104$, II 8 .

(9) Pedrazzini/Oberholzer, sh, 123; Oberlin, sh. 125; BGE 95 IL 58.

(10) BGE 104 II 8 vd yahut JdT 1978 I 592-593, cons. 2a. Ayrica bk. BGF 11 I II 337

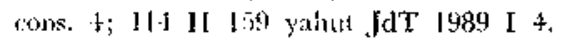


varlığının temellerì tehlikeye düştüğü takdirde- ahlâka aykırı sayılır (bk̉. BGE 102 II 218, Erw. 6; 88 II 174; 53 II 320)".

\section{Topyekûn temlikin MK m23/II, BK m. 19/II ve 20 tle Illişkisi:}

Isviçre-Türk Borçlar hukukunda mevcut ve gelecekteki tüm alacakların temlikini yasaklayan bir hüküm bulunmamaktadır. Bu itibarla topyekün temlikin geçerliliği, onun, şahsiyet haklarmm kanuna ve ahlaka aykırı olarak sınırlandırılmasını yasaklayan MK $\mathrm{m}$. 23 / II ile BK m. 19/II ve 20 hükümlerine aykıri olmamasına bağli$\operatorname{der}(11)$.

Isviçre Federal Mahkemesi, temlikle iktisadi hürriyetin şahsiyet hakkıyla bağdaşmıyacak ölçüde sınırlandırılması ve ayni zamanda ahlaka aykırı akdi tasarrufta bulunulmarı halinde, sahsiyet haklarmm ihlâl edildiğini kabul etmektedir (12). İsviçre yüksek mahkemesi ve doktrin topyekün temlik sözleşmesinin ne zaman ahlaka ve şahsiyet haklarına aykırı sayılacağı hususunda genel bir hüküm verilemiyeceği; yargıcın somut olayın özelliklerine ve menfaatler durumuna göre bu hususta karar verebileceği görüşündedir (13). Temlik edenin geniş kapsamlı bir temlik sonucu gelecekteki işletme vasıtalarından ve ber türlü kazanç imkânlarından yoksun kalması halinde şahsiyet haklarının ihlâl edildiği kabul edilir. Keza temlik edeni aşırı ölçüde bağlayan ve onun hareket serbestisini daraltan temlik ahlâka aykırı saylur (14).

Böyle bir durum söz konusu olmaksızın, topyekün temlikinin süresinin uzunluğu, edim karşı edim dengesinin bulunmaması ve kredi alanının iktisaden zayıf olması, şahsiyet haklarmın ihlâl edildiği anlamina gelmez (15).

Şahsıyetin hukuki işlemden kaynaklanan ihlâllerini yaşaklayan MK $m$ 23/II hükmü, hükmi şahıslar hakkında da uygulanır.

(11) Zobl, Syst Teil, N. 1676; ayni yazar, SJZ 1989, sh. 354; Oberlin, sh 136. -

(12) BGE 106 II 377 cons. 4; 112 II 243, 435.

(I3) BGE 106 II 379; 112 II 436 Erw. 3 yahut JdT 1987 I 165; Zobl, Syst Teil, N. 1677; Ayni yazar SJZ 1989, sh. 354, dn. 55 e ait metin; Staehelin, sh. 385 vd; Twor/ Schnydex, sh. 84; Haensler, sh. 105 N. 4, dn. 9'a ait metin.

(14) Oftinger/Baer, Art. 899, N. 72; Zobl, Syst Teil, N. 1676; Amonn, Blatter, sh. 133; Oberlin, sh. 137; Haensler, sh. 105 N. 4; Albisetti/Boemle/Ehrsam /Gsell/ Nyffeler/Rutschi, sh. 337 vd.

(15) Zobl, Syst Teil, N. 1677; ayni yazar, SJZ 1989, sh. 354; Grossen, sh. 13; Bergmaier, sl., 107. 
Ancak hükmi şahıslar için söz konusu olacak koruma, gerçek kişilerinki kadar geniş olamaz (16). "Şüphesiz, bir hükmi şahıs, kabul edilemez bir tahdit olmaksızın, hürriyetini tamamen kendisiyle bağl.lığı olmayan ü̧̧üncü şahıs lehine devredemez. Fakat bağlı olduğu şahıslarla ilişkide durum farklıdır (Egger, Art. 53, N. 17). Hükmi şahıslarm üyelerinin veya üçüncü şalııların korunmaya değer varlıkları ihlâl cdildiği takdirde, hürriyetin kabul edilemez bir tahdidi söz konusu olur; böylece azınhı̆ın haklarımın korunması ve "şeffafhk ilkesinin" uygulanması için MK m. 23/Il'ye başvurulur" (17).

Mevcut ve müstakbel her türlü alacağın konu ve zaman simurı olmaksızın topyekün temliki MK m. 23 anlamında ahlâka aykırı ve bâtıldır (BK m. 19/II ve 20). Buna karşıllık konu ve zaman bakımından sınırlı bir topyekün temlik, şahsiyet haklarına aykırı sayılmaz ve geçerlidir (18).

\section{1- Topyekün Temlikin konu baktmindan stnerlan}

a) Temlik edilen alacağnn konusu açısindan sımırı

Temlik edilen alacak hukuki sebep veya borçlu çevresì bakımın-

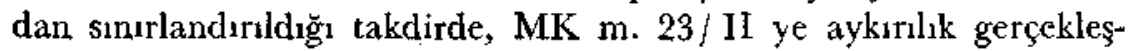
mez. Temlik eden in belirli bir ticari işletmesinden, teslimatindan veya hizmet ediminden doğan mevcut ve müstakbel her türlü alacăğnı temlikinde durum böyledir (19). Elverir ki, böyle bir temlik, temlik edeni bütün işletme vasıtalarından ve kazanç :mkânından yoksun birakmasin (20).

(16) BGE 106 JI 378; Jaeggi, ZSR 1960, sh. 217a ve 223a; Zobl, Syst Teil, i. 1677; Haensler, sh. 106.

(17) BGE 106 II $378-379$.

(18) Zobl, Syst Teil, N. 1678; ayni yazar, SJZ. 1989, sh. 354; Bergmaier, sh. 106; Staehelin, sh. 385 vd; Amonn, Blatter, sb. 132; Oberlin, sh. 132 vd; Haensler, sh. 107; von Tohr/Escher, sh. 350; von Bitren, sh. 324; Guhl/Merz/Kummer, sh. 235; Gauch/SchInep/Jaeggi, N. 2200; BGE 84 II 366, Erw. 3 yahut JdT 1959 I 203, cons. 3; 112 II 436 Erw. 3 yahut JdT 1987 I 165, cons. 3.

(19) Zobl, Syst. Teit, N. 1666 ve 1679; ayni yazar SJZ 1989, sh. 354-355; von Tuhr/ Escher, sh. 350; Gauch /Schluep, N. 2199; Staehelin, sh. 385; Emch/Renz, sh. 284 vd; Albisetti/Boemle/Ehrsam/Gsell/Nyffeler/Rutschi, sh, 337-338; Haensler, sh. 107, N. 7; Oftinger/Baer, Art. 899, N. 72; Oftinger, Bundesgerich। praxis, sh. 202; Amonn, BJatter, sh. 132 vd; Bergmaier, sh. 106; BGE 69 II 292 yahut JdT 1944 I 190; 112 IJ 437; 113 II 165 cons 2a; Nobel, sh. 358 vd da yaymlauan 8.8.1977 tarihli yayınlanmamıs Federal Mahkeme kararı.

(20) BGF 69 II 292 yahut J J' 1944 I 190, cons. 2a; Oberlin, sh. 140; Haensler sh. 107. 
Buna karşllık, temlik edenin herhangi bir üçüncü şahistan herhangi bir zamanda sahip olacağı her türlü alacağın devri caiz değildir (21).

b) Teminat altına alınan alacaklar çevresi

Topyekûn temlik, teminat amacma hizmet eder; temlik eden teminat amacıyla temlik ettiği alacaklar karşılığı genellikle sürekli değişen bir banka krediși şeklinde bir karşı edim elde eder. Bu çerçevede, temlik edilenin devredilen alacakları tahsil etmesiyle, temlik edenin borcu azalır ve artan kredi limiti dolayısıyla onun iktisadi durumu kuvvetlenmiş olur. Bu itibarla, topyekûn temlik işlemiyle MK m: 23/II hükmü ihlâl edilmemektedir (22).

Topyekün temlik, miktarı sabit olmayan, değişen banka kredilerini (revolvierenden Bankkrediten) (23) teminat altina almak amacıyla yapıldığı için, devredilen alacaklar kredi limitini önemli ölçüde aşabilir. Isviçre bankacılık uygulamasında $\% 50$ oranında bir güvenlik marjı normal sayılmaktadır (24).

Topyekün temlikle teminat altına alınan alacak miktarının özel kredilerle sinıtlı olması geıekmez. Topyekûn temlikle, bankayla önceden kurulmuş veya mevcut iş ilişkisi çerçeveșinde ilerde kurulacak sözleşmelerden doğacak bütün alacaklar teminat altına alınabilir (25). Buna karşılık, açık bit anlaşma olmadıkça, devralanmm mevcut iş ilişkisinden bağımsız olarok, temlik edenin. diğer alacaklılanndan kazandı̆̆ı her türlü alacakıarı teminat altına alması caiz sayılmamaktadır (26).

(21) Zobl, Syst Teil, N. 1679; ayni yazar, SJZ 1989, sh. 355; Gauch/Schluep, II, N. 2200; von Tuhr/Escher, sh. 350; Staehelun, sh. 385; Amonn, Blatter; sh. 133; Fromer, sh. 308; Guhl/Merz/Kummer, sh. 235; BGE 84 II 366 Erw. 3 yahut JdT 1959 I 203; BGE II2 II 436 Erw. 3 yahui JdT 1987 I 165 cons. 3.

(22) Zobl, Syst Teil, N. 1680; Oberlin, sh. 141 vd; Haensler, sh, 108; Kaderli, sh. I09; BGE 69 II 292 yahut JdT 1944 I 190; Nobel, sl. 360'da yer alan 8.8.1977 tarihli yayınlanmamıs Federal Mahkene karar.

(23) bk. Albisetti/Boehmle/Ehrsam/Gsell/Nyffeler/Rutschi, sh. 105 vd.

(24) Zobl, Syst Teil, N. 16i0; Haenaler, sh. 108-109; Oberlin, sh. 142; Kleyling sh. 77.

(25) Zobl, Syst Teil, N. 1681; ayni yazar SJZ 1989, sJ. 355; Obexlin, sh. 141.

(26) Zobl, Syst Teil, N. 1681; ayni yazar, SJZ 1989, sh. 355, dn. 60 a ait metin; Oftin* ger/Baer, Arî. 884, N. 129; Begmaier, sh. 106 vd; BGE 51.11282. 


\section{Topyekür Temlikin Kaman Bakımundan Suntar:}

İsviçre bankaları çok ender hallerde topyekûn temliki belirli bir zaman dilimiyle sin.rlamaktadır (27). Ancak teminat konusı alacakların konu bakımından sınırlandırılması zaman bakımından sınırlamayıda tazammun eder (28). Belirli bir krediyi teminat altma almak için yapłlan temlikler, kredi ilişkisinin sona erdiği ve kredinin bankaya ödendiği anda varlıklarını kaybederler (29). Bu durumda, kredi alacağına kavuşan banka, teminat konusu alacakları temlik edenc devirle yükümlüdür. Keza, taraflar, topyekün temlikin banka ile temlik eden arasındaki iş ilişkisinin devamıla sınırlı olduğunu kararlaştırabilirler (30). Buna karşılık banka ilc temlik eden arasındaki iş ilişkisindan bağımsız olarak süresiz devem edecek bir topyekûı tomlik, zaman ve konu bakımundan sı irstz oldığu için ahlâka aỵkın sayı$\operatorname{lir}(31)$.

\section{MK m. 23/ II ye Aykın Topyekün Temlikin Sonuçları}

Şahsiyet haklarma ve ahlâka aykırı (MK m. 23/II) topyekûn temlik işlemi, BK m. 20/I gereğince bâtıldır (32). Burada tam butlan söz konusudur.

BK m. 20/II'de öngörülen lısmi bulanın, şartlart varsa topyekûn temlike de uygulanabileceği doktrinde kabul edilmektedir (33). Zira BK m.20/II anlammda kısmi butlan, sadece yan yükümlerde değil, asli yüikümlerde de uygulama alanı bulur (34). Böylcce temlik, kredi ilişkisinin devamıłta sınırlandırslabilir veya temlik cdilen aliı-

(27) Zobl, Syst Teil, N. 1682; ayni yazar SJZ 1969, sh. 355. Haensler, incrlediği isviçre bnnkalarma ait cip sözle omelerde topyckùn temlikin zaman açsumclau smorlindırilmasma rastlamadığını söylentektedir (sh, 109).

(28) Zobl, Syst Teil, N. 1682; ayni yazar SJZ 1989, sh. 355; Haensler, slı. 109.

(29) Zobl, Syst Teil, N. 16E2; ayni yazar, SJZ 1989, sl. 35.5; Haensler, s], 109 ; Amonn, Blatter, sli, 133.

(30) Zobl, Syst Teil, N. 1685; ayni yazar, SJZ 1989, sh. 3.55; Haensler, sh. 109.

(3) Zobl, Syst Tejl, N. 1684; ayni yazar, S5Z 1989, sh. 355; Oberlin, sh. 138; Staehelin, sh. 385; BGF, 84 IJ 366-367 yahut JdT 1959 l 203.

(32) Zobl, Syst T'eil, N. 1685; ayni zaya', SJZ 1989; sh. 355; Oftinger /Baer, Syst Tcil, ‥ 281 ; Becker, Art. 20, N. $7 / 8$; Wollf, sh, 222; Bergmaier, sh. 101 ; Fromer, sl. 308; Haensler, sh.1 10, N. 9; Oberlin, sh. 144; BGE, 112 Il 436 .

(33) Zobl, syst 'Teit, N. 1685; ayni yazar, SJZ 1989. slı. 355; Staehelin, slı. 385; Haensler, sli. $1 \mathrm{1} 01111$; Oberlin, sh. $145 \mathrm{vd}$.

(34) Oser/Schöneneberger, Art. 20, N. 68; von Tuhr/Peter, sh. 262; Zobl, Syst Teil N. 1685; Bucher, sl. 238; vd; Oberlin, sl. 146-147 Haensler, sl., 111; BGE. 80 II 231; 93 II 192; 107 II 218. 
cağın kapsamı ahlâka ve şahsiyet haklarına aykırı olmayacak derecede daralthlır (35).

Isviçre Federal Mahkemesi 1980 y linda verdiği kararda (36), ayni yöndeki eski kararlarına (37) da atıfta bulunmak suretiyle, MK m.23/II ye aykırı bir işlem:n tam butlan ile geçersiz sayılmayıp, uygun ölçüye getirilmesi gerektiğine hükmetmiştir. Buna karşllı 1986 tarihli kararında, BGE 106 Il 379 'da ifade edilen kısmi butlana jliş. kin mülahazaları isabetli bulmakla beraber (38), hakkında hüküm verdiği olayda kısmi butlanı şu gerekçelerle reddetmektedir (39): "Temlikin bu şekilde kısmi butlanı kabul edilirșe, bu, temlik edilen alacağın doğduğu veya ileri sürüldư̆ğü anda, yukarda zikredilen ya. zarlarn kabul ettiği anlamda belirliliğe ilişkin ılımlı niteliklerle dahi hiç bağdaşmayan güvensizliği mucip olacaktır. Düşünülebilen her türlü alacağm topyekûn temlikinin batıl olması halinde, temlik edilen alacağın bớçlusu kendisinden talep edilen alacağın kısmi butlana dahil olup olmadığını bilemeyecektir".

Federal Mahkemə̃nin bu kararında ileri sürlen mülahazalara katilmak mümkün değildir. Zira MK m. 23/11 ile temlik eden yönünden getirilen kısıtlamalar temlik borçlusunun durumu üzerinde herhangi bir etkide bulunmaz. Temlik ihbarının yapılmamasinin temlik edilen alacağın borçlusu üzerine yaratacağı belirsizlik BK $\mathrm{m}$. I65 ile çözümlenmiştir. Federal Mchkeme, temlik akdinin muhtevasının belirsizliği ile sözleşmenin taraflardan birini ahlâka aykurı yükümler altında bırakmașı hu, uslarını birbirine karıştırmış bulunmaktadir (40).

(3.5) Zobl, Syst Teil, N. 1685.

(36) BGE 106 II 379.

(37) BGE 97 II 399; 93 II 300; 62 II 35; 43 II 662 .

(38) BGE 112 II 437.

(39) BGE 112 II 438 yahut JdT 1987 I 166.

(40) Oberlin, sh. 149, dn. 100. Ayrrca bk. Haensler, sh. 112-113, N. 13. 


\section{§7. ÇİFT VEYA BIRDEN ÇOK TEMIIIK}

Uygulamada, iktisadi güçlük içinde olan ve bu sebeple yeni kredi arayan şahıs veya firmaların, topyekûn temlik çerçevesinde daha önce temlik ettikleri alacaklarını ikinci def'a temlik ettikleri görülmektedir. Alacaklının ayni alacağı birden çok temlik etmesi olayı ile karşılaşılmasının sebebi, yazılı şekilde düzenlenen temlik sözleşmesinin, bu sözleşmenin tarafı olmayan kişiler açısından aleniyet sağlayan bir fonksiyousun bulunmamasidir (1).

Çift temlik halinde ilk (eski) temlik işlemi geçerlidir. Bu busus, temlikin bir tasarruf işlemi olmasının sonucudur. Zira tasarruf işlemlerinde öncelik ilkesi (Prioritaetsprinzip) geçerlidir (2). Alacă̆ı yeni devralanın eski temliki bilip bilmemesi bu konuda önemli değildir. Hatta bu durumda tasarruf işlemi olarak çifte veya birden çok temlikten söz etmek isabetli değildir. Çünkü birinci temlikin yapıldı̆̆ı andan itibaren, temlik eden, alacaklı sıfatını ve tasarruf yetkisini kaybetmiş bulunmaktadır (3).

Kanun, iyiniyetli temlik borçlusunu, çift veya birden çok temlikin arzettiği risklere karşı korumuştur (BK m. 165 ve 168). Bu korumanın sebebi, alacağın temlikine temlik borçlusunun katılmasının gerekli olmamasıdır (BK. m. 162/I). BK m. 165'e göre, çift veya bjrden çok temlik halinde, kendisine temlik ihbarı yapılmayan temlik borçlusu, iyniyetle gerçek hak sahibinden (alacakhdan) başkasina edada bulunmuşsa borçtan kurtulur. Bu cümleden olarak, kendisine sadece ikinci temlikin bilidirimesi halinde, ikinci t:mlikin alacaklısma iyiniyctle ifada bulunan temlik borçlusu, birinci temlikin alacaklısına karşı edimde bulunmakla yükümlü olmaz (4). Her iki temlik kendisine bildirilmeyen temlik borçlusunun, iyniyetle temlik edene edada bulunması ihtimalinde de, ayni sonuç hasıl olur (5).

(1) Zobl, \$1Z 1989, sh. 356; Haensler, sh. 154, N. 2.

(2) von Tuhr/Escher, sh. 338, 360 vd; Guhl/Merz/Kummer, sh. 238; Bucher, sh. 548; Zobl, Syst Teil, N. 1622; ayni yazar, SJZ 1989, sh. 356; Gauch/Schluep, 11, N. 2232; Haensler, sh. 156, N. 7; Staehelin, sh. 383.

(3) Haensler, sh. 156, N. 7. Aynca bk. Bucher, sh. 548 dn. 50.

(4) Zobl, S]ZZ 1989, sh. 356, dn. 77 ye ait metin; von Tuhr/Escher, sh. 361; Gauch/ Schluep, II, N. 2232; Bucher, sh. 563 vd; Guhl/Merz/Kummer, sh. 239.

(5) Zobl, SJZ, sh. 356, dn. 76'e ait metin; von Tuhr/Escher, sh. 358; Gauch /Schluep 11, N. 2225; Guhl/Merz/Kummer, sh. 239; Bucher, sh. 561-562; Haensler, sh. 157. 
Gift temlik halinde, alacağına yukarda açıklanan sebeplerle kavuşamayan birinci temlik alacaklısı (temellük eden) için başlıca iki hukuki imkân vardır: $O$, temlik edene karşı ikinci temlikle uğradığı zararın tazminni isteyebileceği gibi (BK m. $96 \mathrm{vd}$ ), sahip olmadı bir alacağı tahsil eden ikinci temlikin alacaklısına karşı BK m. 61 vd gereğince sebepsiz zenginleşme davası da açabilir (6).

Isviçre Federal Mahkemesi 1985 yılında verdiği yayımlanmamış bir kararında (7) benzer bir durum hakkunda içtihatta bulunmuştur. Karara konu teşkil eden olayı şu şekilde özetlemek mümkündür: A bankası Z AG'ye (bir anonim şirket) hizmet edimleri ve mal tesliminden doğan defter alacaklarmın topyekûn temliki karşlığında 28 Eylül 1978 tarihịinde bir temlik kredisi açmıştır. Bu temlik, temlik borçlusuna ihbar edilmemiştir. Z AG, 30 Ocak 1981'de bir işletme kredisi teminatı olarak mevcut ve müstakbel alacaklarının tamamın $B$ bankasına devretmiştir. Bunun üzerine, sağlanan krediyi ödemek üzere B bankasina külliyetli miktarda ödemelerde bulunulmuştur. Z AG 18 Eylül 198l'de iflâs eder. A bankası iflûsla karşılanmayan 20.000 frankın ödenmesi için B bankasına karşı BK 61 gereğince dava açmıştır. A bankasi, kendisine yapilan ilk temlikten sonra B bankasina yapilan ikinci temlikin geçersiz olduğunu ve yaplan ödemelerin sebebsiz zenginleşme teşkil ettǐ̆ğini ileri sürmüş̧ür.

Federal Mahkeme davayı şu gerekçelerle reddetmiştir: Sebepsiz zenginleşme borçlusu, başkașının mamelekinden zenginleşen kimsedir. Zenginleşme ile fakirleşme arasında doğrudan doğruya bir bağın bulunması gerekir. Doğrudan doğruya bağın bulunması zarureti, zenginleşme konusunu ilk fakirleşenden değil, -ilk zenginleşenle kendisinin yaptığı sözleşmeyle- dolaylı olarak kazanan üçüncü şahısların, zenginleşme borçluları arasında sayılmamasını gerektirmektedir. Burada doğrudan doğruya zenginleşmeyi doğrudan doğruya kazandirmayla es tutmamak gerekir. Doğrudan doğruya kazandirmalar, kazandırma lehdarinı sırf dolaylı olarak zenginleştirebilirler (von Tuhr/Peter, sh. 199 vd).

Ilk temlik ile Z AG nin alacaği davacıya geçer ve temlik eder artık onun üzerinde tasarrufta bulunamaz. Bu itibarla davalıya yapılan yeni temlik geçersizdir. Z AG, borçlusundan, davalıya edada bulunmasını isteyerek, alacağın ifa ile sona ermesine katkıda bulunmuştur.

(6) von Tuhr/Escher, sh. 361, dn. 25'e ait metin; Zobl, SJZ 1989, sh. 356; Gauch/ Schluep, II, N. 2326; Bucher, sh. 562; Guhl/Merz/Kummer, sh. 259; Kleyling; sh. 38; Haensler, sh. 160 vd, özellikle, sh. 166, N. 36.

(7) Bu kararın metni için bk. Zohl, SJZ 1989, sh. 356 vd; Heengler, sh. 162 vd. 
Ikinci temlik, ilk plânda temlik edeni ilgilendiren bir teminal amacıyla temliktir. Bu temlikin amacı, davalıdan aldı̆̆ı karzı ödemektir. Z AG temlik borçlusundan, (ikinci temlik alacaklısı) davahya ödemede bulunmasim talep etmek suretiyle, dolayl olarak davacının mamelekinden davalyya edimde bulunmasım sağlamı̧ olmakta; borçlular da, davalıya doğrudan doğruya kazandırmada bulunmuş olmaktalar. Bununla beraber, Z AG'yı doğrudan zenginleşen olarak mütalaa etmek ve onun parayı fiilen aldıktan sonra $B$ bankasına yatırmıs saymak zarureti vardır. Z AG, temlik borçlularından, davalı nezdindeki hesabına ödemede bulunmaların istemek suretiyle, borşlulara ödeme yeri göstermiş olmaktadı. Bu itibarla, ödemeleri kabul etmekle davalımın doğrudan zenginleşmediği ve ona karşı açılan sebepsiz zenginleşme davasının reddedilmesi gerektiğ sonucuna varılmıştır.

Federal Mahkemenin söz konusu iç̧thadı doktrinde haklı olarak tenkid edilmektedir (8). Federal Mahkemenin görüşüne göre, temlik edenin göstẻrdiği ödeme yerine tediyeyi, bizzat temlik eden tarafindan yapılmış saymak gerekir; ödeme yerinin borçlunun tediyesinin hukuki sebebiyle bir iliģiği bulunmamaktadır. Banka ile temlik eder arasndaki ilişkinin sadece ödeme yerinden ibaret olduğu hallerde bu görüşe katılmamak mümkün değildir. Oysa olaydaki çift temlikte ödeme yeriyle temellük eden arasında ayniyet bulunmaktadır. Başka bir ifadeyle, banka zahiren ödeme yeri, fakat esasta gizli temellük eden durumundadır (9). Nitekim Alman Federal Mahkemesi benzer bir olayda, geçersiz bir topyekûn temlike dayanan bir ödemenin varlığımı kabul etmiştir (10). Palant/Thomas da, ikinci tamellük edenin sadecc ödeme yeri sıfatını :ier! sürmesizi in, dürüstlük kuralına aykırı olduğunu ifade etmiştir (11).

Diğer taraftan, yapılan ödemeler tahsili mümkün olmayan kredi alacağın azaltıyorsa, değeri olmayan alacak yerine güvenli bir değere kavuşan ikinci temellük eden, birinci temlik alacaklısı aleyhine doğ̣rudan zenginleşmiş sayılır (12).

Buna göre, ilk temlik alacaklısmın (A bankasi), ikinci temlik alacaklısına karşı sebepsiz zenginleşme davası açabileceğini kabul etmek gerekir.

(8) Zobl, SJZ 1989, sh. 357 vd; Haensler, sh. 169 vd.

(9) Haensler, sh. 163-164.

(10) BGHZ 72316.

(11) Palant/Thomas, $\$ 816$, N. 4.

(12) Zobl, SJZ 1989, sh. 358; BGE 92 II $340 \mathrm{vd.}$ 


\section{§ 8. IFLÂSTA TOPYEKÜN TEMLIK}

Iflâsın topyekûn temlike etlisini temlik eden ile temellük edenin iflâsına göre, iki kısımda inceliyeceğiz. Son olarak da iptal davasınin topyekûn temlikte mümkün olup olmadığına temas edeceğiz.

\section{I- Temlik edenin iflâsı}

\section{Gemel olarak}

Borçlunun iflâsı açıldıktan sonra onun mal varlı̆̆ı üzerindeki tasarruf yetkisi sona erer (1tK m. 191/I). Ayni şekilde, iflâsın açıldığı zaman iflâs edenin haczi kabil malvarlı̆̆ bir masá teşkil eder ve ałacakların ödenmesine tahsis edilir (IIK 184/I). Borçlunun malvarlığı üzerinde tasarruf ve taahhüt muamelesi yapma yetkisi iflâs idaresine geçer (ItK m. 226 vd).

Bu durumda iflâsın açlmasından önce devredilen, fakat iflâsm açılmasından sonra doğan alacaklara hangi esasalarin uygulanacăğnın tesbiti önem taşımaktadır.

\section{Zaman baktmindan stnirlama}

Işlâsın açıldı̣̆ı anda iflâs edene karşı mevcut alacaklar, iflâs alacă̆ı sayılır. Buna karşılık iflâs açıldıktan sonra masa veya iflâs eden borçluya karşı doğan alacaklar iflâs alacağı sayılmaz (1). Bir alacak doğum sebebinin mevcut olduğu andan itibaren varlık kazanır. Başka bir ifadeyle hukuki sebebin (causa) iflâsın açılmasından önce gerçekleşmesi yeterlidir (2).

IIK m. 195/I'e göre, borçlunun gayrimenkul mallarının rehni suretiyle teminat altına alınan alacaklar müstesna almak üzere, iflâsin açilmasıyla, iflâs edenin borçları muaccel olur. Böylece daha önce muaccel olan alacaklarla henüz muaccel olmamıs alacaklar ayni işleme tabi tutulmuştur. Bunun sebebi, ItK nun, borçlar hukuku anlaminda muacceliyeti, bir imtiyaz sebebi yapmaktan kaçınmak sstemesidir (3).

Doktrin ve uygulamada (4) alacağın muaccel olduğu veya talebin kapsam ve mevcudiyetinin kesin olarak belirlendiği tarihler yerine,

(1) Blnimenstein, sh. 658; Amonn, Grundriss, sh. 334; Oberlin, sh. 153.

(2) Oberlin, sl. 153.

(9) Amonn, Grunciriss, sh. 334; Blumenotein, sh. 660. 
sadece alacağın hukuki sebebinin doğduğu an ölçü olarak ahnmaktadır. Bu itibarla, taliki şarta bağlı veya vadesi belirsiz alacaklarla iflâs eden borçlunun kefalet alacaklan (ItK m. 202/I) iflâs masasına dahil olur (5).

\section{Iflasin temlik üzerine etkileri}

a) Iflâsın açılmasından sonraki temlik

Iflâs açıldıktan sonra iflâs borçlusu masaya ait haklar üzerinde tasarruf işlemlerinde bulunamaz; alacağın temliki de bir tasarruf i̧̧lemi olduğu için, masa alacaklarını temlik edemez (6). Buna karşılık, iflâs masasına girmeyen ve iflâstan sonra kazandı̆ı ücret alacaklarını temlik edebilir (7).

b) Iflâs açılmadan önceki temlik

aa) Mevcut alacaklar

Iflâs açılmadan önce iflas borçlusu tasarruf yetkisine tam olarak sahip olduğu için, bu dönemde yapılan alacak temlikleri iflas masasına girmez; temellük eden kişinin mamalekine girer. Bu durumda, iflâs masası muvazaa veya $1 \hbar \mathrm{K}$. 277 vd anlamında iptal davası açmaktan başka imkâna sahip değildir (8).

Böyle bir temlik halinde, temlik borçlusu doğrudan temellük eden kimseye ödemede-bulunabilir. Buna karşllk, temlik kendisine ihbar edilmeyen iyiniyetli temlik borçlusu, temlik edene ödemede bulunursa borçtan kurtulur (BK m.165). Kendisine temlik borçlusu tarafından ödemede bulunulan temlik eden iflâs èderse, temellük eden ayırma hakkına sahip olacak midır?

Temlik edene ödeme onun iflâsından önce yapılmışsa, temellük eden iflâsın ilânından sonra sadece iflâs alacaklısı olarak alacağını ileri sürebilir, Buna karş̧lık iyniyetli temlik borçlusu ilfâs açıldıktan sonra iflâs masasına ödemede (IIK m. 19l) bulurmuşsa, temellük edenin IIK m. 189 gereğince, ayırma hakkına sahip olduğu kabul edilmektedir $(\varphi)$.

(4) Amonn, Grundriss, sh. 335; Blumenetein, sh. 660 vd; Obexlin, sh. 154; BGE 107 III 143 vd.

(5) Oberlin, sh. 154 .

(6) Kuru, sh. 180.

(7) Knru, sh. 180, dn. 5; Oberlin, sh. 154.

(8) Jaeger, art. 197, N. 1, sh. 119; Oberlin, sh. 155.

(9) Jaeager, art. 202, N. 2, sh. 154-155; Bergmaier, sh. 218 vd; Oberlin, sh. 156; BGE 70 III 84, 87 II 19; 90 III 90. Aksi fikirde: Blumengtein, sh. 764; Kleyling, sh. 48 . 


\section{bb) Müstakbel Alacaklar}

Temlik edenin, iflâs açılmadan önce topyekûn temlik çerçevesinde iemlik ettiği müstakbel alacaklar, iflâs açılmadan doğarsa, temellük edene geçer (10).

Buna karşılık, iflâs açılmadan topyekûn temlik konusu olan, iflâs açıldıktan sonra doğan müstakbel alacaklar iflâs masasına girer (11). Alacağın temliki konusunda kabul edilen, önceden tasarruf edilebilirlik (Vorausverfügbarkeit) kavraminda tasarruf fili ve tasarruf sonucu arasında ayırım yapılmaktadır (12). Tasarruf fiilinin yapıldı̆̆ı anda, temlik edenin tasarruf yetkisine sahip olmasinı yeterli saymak, henüz konusu oluşmamış, maddi muhtevadan yoksun bir temliki kabul etmek gibi bir güçlüğü beraberinde getirir (13).

Diğer tàraftan, müstakbel alacakların iktisabı konusunda mevcut olan "geçiş teorisi" (Durchgangstheorie) (14) de, "doğrudan doğruya iktisab teorisi" (Unmittelbarkeittheorie) (15) de, temlik edenin alacağın doğduğu anda tasarruf yetkisine sahip olması şartını aramaktadır. Bu iki teori açısından da iflâs açıldıktan sonra doğan alacaklar iflâs masasına dahil olur (16).

Bu çözüm tarzı iflâs hukukunun amacına da uygundur. Zira iflâsta alacaklıların eşit bir şekilde muamele görmessi asıldır (17); hiç bir alacaklı diğer alacaklılar aleyhine çıkar sağlayamaz. $11 \mathrm{~K}$ m.206' da saylan imtiyazh alacaklar arasinda, müstakbel alacaklar yer almamaktadır. Şayet iflâs açıldıktan sonra, iflâs idaresince yürütülen faaliyetlerden doğan alacakların temellük edene ait olduğu kabul edilecek olursa, bundan, iflâs masasının küçülmesi sebebiyle, diğ̌er alacakhlar zarar görecekiri (18).

(10) Amonn, Blatter, sh. 136; Oberlin, sh. 155; Heeneler, sh. 121-122.

(11) Amonn, Blatter, sh. 136-137; Oberlin, sh. 158; Haenoler, sh: 124 vd.

(12) bk. yukarda, \$ 4 .

(13) Amonn, Blatter, sh. 136; Obertin, sh. 157-158.

(14) Geçis teorisine göre, ajacakiar mantıken bir saniyelik temlik edenin sahsında dos. duktan sonra-tasarruf sözleşmesi scbebiyle-otomatik olarak temellük edene geçer. Bk. Oeer/Schönenberger, art. 164, N، 4; Wollf, sh. 224 vd; Zobl, Syst Teil, N. 1571; Bucher, sh. 547; Keller/Schbbi IV, sh. 60; Gauch/Schluep II, N. 2197.

(15) Bu tẹoriye göre, temlik edilen müstakbel alacaklar doğudan doğruya temellük edenin sahsinda dogar. bk. von Tuhr/Escher, sh. 349; Guhl/Merz/Kummer, sh. 235; Becker, Art. 164, N. 16; Kleyling, sh. 77 vd.

(16) Haensler, sh. 123, N. 15.

(17) Kuru, sh. 246; Faensler, sh. 124; Amonn, sh. 282, N. 3.

(18) Oberlin, sh, 158, dn. 27; Haensler, sh. 124-125; Amonn, Blatter, sh. 136. 


\section{II- Temellïk edenin tflâsı}

Teminat amacıyla inançlı temliklerde inamlan temlik konusu alacak üzerinde $\tan$ hak kazanır; inanau inanç konusu alacağın kendisine devri konusunda, inamilana karşı sadece şalısi bir talep hakkma sahiptir (19).

Inanilanın (temellük edenın) iflâsı halinde, inançlı temlikle ona devredilen alacaklar da iflâs masasına girer ( $\mathrm{IJK} \mathrm{m} .184$ ). Bu durumda, temlik eden (inanan) iflâs masasına karşı ileri sürülebilecek bir ayırma hakkına sahịp olacak mıdır? tsviçre-Türk hukukunda, inananın ayırma hakkına kanuni dayanak olarak BK m.393 hükmü gösterilebilir.

Inananın korunmasında BK m. 393'e dayanma imkànı son dèrecede tartışmalı bir husustur (20). Inanç anlaşmasını alelâde bir vek9let olarak niteliyen Gautschi'ye göre (21), BK m. 3â3, taşınmazlara ilişkin olanlar dışında, bütün inançh işlemlerde uygulanır. Bu yazar, dolaylı temsil yoluyla ifa edilen vekâletle inançh işlem arasında bir fark bulunmadığı fikrindedir (22). Buna karşılłk bazı yazarlar, BK m. 393'ün inançlı işlemlerde hiç uygulanamayacağ 1 görüşünü savunurken (23), bazıları da (24) ancak inanılanm üçüincü kişilerden kazandı̆̆ı alacaklar ve şeyler için uygulanabileceğ $i$ kanaatindedir.

Kanaatimizce BK m. 393 hükmü ancak inanılanın üçüncü kişilerden kazandığı alacaklara uygulanır. Bizzat inananın inanılana temlik ettiği alacaklar için BK m. 393'ün uygulanócağı' söylemek tatmin edici bir yorum saylmaz. Inananin korunması, ancak de lege feranda BK m. 393 ün tamamlanması suretiyle gerçekleşebilir (25).

\section{(ttK m.277-284)}

Iflâs açılmadan önce tasarruf yetkisi henüz kısıtlanmayan kimselerin, iflâs etmek üzere iken, mal varlığına dahil değerleri alacaklıla-

(19) bk yuk. $\$ 92$, IIJ.

(20) Bu hususta ileri sürülen çeşitli fikirłerin değerlendirilmesi ve izałı için bk. Tandogan, C. II, sh. 552 vd.

(21) Art. 394, N. 13, a-c, 56, 58; Art. 401, N. 15.

(22) Art. 401, N. 15.

(23) bk. Walli, sh. 35-3!, 101-120; Raymond, sh. 57; Ösunay, sh. 207--2(88, 236. 237.

(24) Bergmaier, sis. 213 vd; Keller, sh. 70 vd; Merz, Legalzession, il. 464.

(25) Merz, Legalzession, sh. 464; Tandoğan, II. sh. 563; Oberlin, sh. 162, 164. 
rından kaçırmak için, bazı (hileli) tasarruflarda bulundukları görülmektedir. Bunun sonucu olarak, borçlu iflâs edince iflâs masasłna çok az bir malı girmekte ve bunlar alacağını karşılamaya yetmemektedir. Bunu önlemek için İcra ve Íflâs kanununda, alacaklılara iptal davası açma imkânı öngörülmüş̧tür (IİK m.277-284). Borçlunun iflas etmeden önce alacaklılarından mal kaçırmak için yaptı̆̆ bağışlamalar ile şüpheli (hileli) tasarruflamn iptali için alacaklıların açacağı̆ davaya iptal davası denir (26). Iflâs açılmadan önce borçlunun temlik çerçevesinde yaptı̆̆ı temlikler de, iptal davasına konu olabilir.

\section{1. İvazstz tasarruflarnn iptali (IIK m. 278) .}

IIIK m. 278'e göre, mutad hediyeler hariç, borçlunun iflasın açılmasından iki yıl önce yaptığı bağışlamalar ile ivazsız tasarrufları iptal edilebilir. Bu maddenin 3. fikrasında 3 bend halinde saylan kazandırma ve akitler kanun gereği bağışlama hükmüne tabi tutulmuştur.

Topyekûn temlikin ivazsız yapılması ancak başkasımm borcunu teminat altına alma amacıyla gerçekleştirilen temliklerde söz konusu olabilir (27). Kendi borcu için teminat verme hali, aciz halinde iken yaplan tasarruflara (ItK m. 279) ilişkin esaslara göre değerlendirilir (28). Bu bakımdan banka uygulamalarında bu tür inançlı temlike rastlanmamaktadır (29).

\section{Aciz halinde iken yapnlan temlikler (IIK m. 279)}

Borcunu ödemeyen bir borçlu tarafindan iflâsın açılmasından önce bir sene içinde, "borçlunun teminat göstermeyi evvelce taahhüt etmiş olduğu haller müstesna, olmak üzere borçlu tarafından mevcut bir borcu temin için yaptlan rehinler" iptal edilebilir (IIK m. 279/ b.1). Teminat amaciyla temlikler, borçluya açılan bir kredinim temini için yapilmıssa maddede geçen rehin kavramına dahil sayılır (30).

(26) Kuru, sh. 375.

(27) Amonn, Blatter, sh. 138; Oberlin, sl. 167; Haensler, sh. 126, dn. 52.

(28) Zob1, Syst Teil, N. 812; Jaeger, Art. 286, N. 3; Amonn, Blatter, sh. I38; Blumemstein, sh. 878 .

(29) Obertin, sh. 167.

(30) Oberlin, sl. I68; Haensler sh. I35; Fritische, Bd. II, sh. 281; Amonn, Blatter, sh. 138 . 
Topyekün temlikin $\ 1 \mathrm{~K}$ m.279/b.1 gereğince iptali açısından bir ylllık sürenin hesaplanmasinda temlik sözleşmesinin kurulduğu anı esas almak gerekir (31).

\section{Diğer Butlan Halleri (IIK $m, 280$ ).}

IIK m.280'de ödeme kabiliyetini kısmen veya tamamen kaybetmişbir borçlunun alaçaklılarının zararına yaptığı hileli tasarrufların iptali düzenlenmiştir. Maddede geçen ödeme kabiliyetini kısmen veya tamamen kaybetme keyfiyeti, genellikle tam veya kısmi borç ödemekten aciz belgesiyle isbat edilir (32). Borçlunun ayni değerde bir krediye kavuşmak için yaptığı (inançli) topyekün temliklerde alacaklılara zarar verme kastından söz edilemez. Meğer ki, borçlu bu temlik sonucu gizli yoldan bir para almı̧ olsun (33).

\section{Bibliyografya}

Albisetti, Z/Boemle, M/Ehrsam, P/Gsell, M/Nyffelex, P/ Rutschi, E. Handbuch des Geld-, Bank-und Börsenwesens der Schweiz, 4.Aufl, Thun 1987.

Akipek, J: Türk Esya Hukuku, C.I: Ziyetlik ve Tapu Sicili, Ankara, 1972.

Amonn, K.: Die generalle Debitorenzession im Konkurs, Blatter für Schuldbetreibung und Korkurs, 1979, sh. 129 vd.

Amonn, K: Grundriss des Schuldbetreibung und Konkursrecht, 4. Aufl, Bern 1988.

Baer, T: Zum Rechtsbegriff der Garantie, insbesondere im Bankgeschaft, Winterthur 1963.

Becker, H: Berner Kommentar, Bd. IV/1, Allgemeine Bestimmungen (Art. 1-183), 2.Aufl. Bern 1941/1945.

Bergmaier, H: Die Sicherungszession im Schweizerischen Recht, Aarau 1945.

(31) Zobl, Syst Teil, N. 815; Fritsche, Bd. II, sh. 280 vd; Oberlin, sh. 171. Aksi fikirde (alaçặı doğduğu anın esas alınması fikrinde); Amonn, Blatter, sh. 138; Haensler, sh. 137 vd.

(32) Kuru, sh. 384 .

(39) Amonn, Platter, sh. 137-138; Haensler, sh. 142 dn. 123'e ait metin. 
Blumenstein, E: Handbuch -des schweizerischen Sshuldbetreibungsrecht, Bern 1911.

Bucher, E: Schweizerisches Obligationenrecht, Allgemeiner Teil, 2. Auf! Zürich 1988.

Bucher, E: Zur Gültigkeit von Globalzession, recht 1989, sh. 12 vd.

'Bucher, E: Kredisicherung durch Zession in: Probleme der Kredisicherung, Berner Táge für juristische Praxis 1981, Bern 19812.

Davran, B: Rehin Hukuku Dersleri, İstanbul 1972.

Egger, A: Zürcher Kommentar, Bd. I, Einleitung und Personenresht, 2. Aufl, Zürich 1930.

Emch, U/Renz, H: Das schweizerische Bankgeschaeft, 3. Aufl, Thun 1984.

Engel, P: Traité des Obligations on droit suisse, Neuchatel, 1972.

Enneeccerus/Nipperdey, Allgemeiner Teil des Bürgerlichen Rechts, Bd. I-II, Tübingen 1959/1960.

Eren, F: Borglar Hukuku, C.I; Ankara 1992; C.III, Ankara 1992.

Flume, W: Allgemeiner Teil des Bürgerlichen Reshts, II Das Rechtsgeschaeft Berlin 1979 .

Fromer, L: Die Abtretung künftiger Forderungen, ZSR 1938, sh. 273 vd.

Gauch/Schluep, Schweizerisches Obligationenrecht, Allgemeiner Teil, 4. Aufl, Bd. I-II, Zürich 1977.

Gautschi, G: Berner Kommentar, VI/2-4, Der einfache Auftrag, Art. 394-4076 OR Berr: 1971.

Grossen, J-M: Traité de Droit Civil Suiss, T. II/2, les personnes physiques Fribourg 1974.

Gugenheim, D: Les ; ontrats de la pratiquz bancaire suisse, 2. éd, Geneve 1985.

Guhl/Merz/Kummer: Das Schweizerische Obligationenrecht, 7: Aufl, Zürich 1980.

Haab, R: Zürcher Kommertar, IV/1, Art. 64l-729 ZGB, 2. Aufl, Zürich 1977.

Heansler, P: Di? Global ession, Zürich 1991. 
Hahnzog. K: Rie Rechtsstellung des Zessionars kïnftiger Forderutgen, Münich 1962.

Homburger, E: Bespreshorg l'on BGE 113 IJ 163, SAG [988, st. 157 vd.

Jaeggi, P: Zur Rechtsnatur der Zossion, SJZ 1971; sh. 6 rd.

Jaeggi/Gauch: Z̈̈ircher Kommertar, V/l b, Art. 18 OR, Züıici 1980.

Jaeger, C: Commentaire de la loi federale sur la poursuite pour detles et la faillite, T.I-III, Lausanne/Geneve 1920.

Jeanpretre, R: La cession de salaire, SJZ 1967, sh. 20 vil.

Kaderli, R: Die Sicherung des Bankkredites, Diss. Bern 1938.

Keller/Schöbi: Das Schweizerische Schuldrecht, Bd. IV: Gemeinsame Rechlsinsitute fiir Schuldverhaeltnisse aus Vertray, unerlaubler Handlung und ungercehtfertiger Bereicherung, Basel 1984.

Klein, F-E: De la Cession globale de creances à titre de garantie, Mélanges Pierre Engel, Lausanne 1989, sh. 207-221.

Kleiner, B: Bankgarantie, 4. Aufl, Zürich 1990.

Kleyling, $\mathbf{T}$ : Zession-unter besonderer Berücksichtigung der Globalzession und Fordenungverpfaendung als Mittel zur Sicherung von Krediten, Züriclı 1980.

Koller, A: Der gute und böse Glaube im allgemeinen Schuldresht, Frciburg 1985.

- Köprülä/Kaneti: Simrh Ayni Haklar, Istanbul 1982/1983.

Kramer, E.A.: Berner Kommentar VI/1/1 (art. 1-2 OR) Bero 1980; VI $/ 1 / 4$ (Art. 18 OR) Bern 1985.

Kura, B: Icra ve Iflâs Hukuku, C. II: Iflâs ve Konkordato Hukuku, Ankara 1971.

Leemann, H: Berner Kommenlar, Die beschraenkten dinglichen Rechte Bern 1925.

Meier-Hayoz, A: Berner Kommentar IV/1/1, Systematischer Teil Allgemeine Bestimmungen Art. 641-654 ZGB, 4. Aufl Bern 1968.

Merz, H: Obligationenrecht, allgemeiner Teil, SPR, Bd. VI/1, Bascl/ Stutgart 1984 . 
Merz, H: Legalzession und Aussonderungsrecht gemaess Art. 401 OR, Erhaltung des Rechtes in der Rechtssprechung des schweizerischen Bundesgerichts, Basel 1975.

Merz, H: Vertrag und Vertragsschluss, Freiburg 1988.

Nobel, P: Praxis zum öffentlichen und privaten Bankrecht der Schweiz, Bern 1979.

Oberlin, B: Die Globalzession in Theorie und Bankpraxis, Diss. Basel 1989.

Oftinger, K: Bundesgerichtspraxis zum allgemeinen Teil des schweizerischen Obligationenrecht, 2. Aufl Zürich 1973.

Oftinger/Baer: Zürcher Kommentar, Bd. IV/2c: Das Fahrnispfand, Art. 884-918 ZGB, 3.Aufl, Zürich 1981.

Oğuzman/Seliçi: Eşa Hukuku, 6. bası, İstanbul 1992.

Oser/Schönenberger: Zürcher Kommentar, Bd. V: Das Obligationenrecht, 1.Teil (Art.1-183 OR), Zürich 1929.

Pedrazzini/Oberholzer: Grundriss des Personenrecht, 2. Aufl, Bern 1985.

Pulaşlı, H: Şarta Bağhl İlemler ve Hukuki Somuglan, Ankara 1989.

Reisoğlu, S: Menkul İpoteği, Ankara 1965.

Reymond, C: Essai sur la nature et les limites de l'acte fiduciaire, Lausanne 1948 .

Schöhle, H: Bank-und Börsentecht, München 1971.

Schönle, H: Die Einmann und Strohmanngeselschaft, Freiburg 1957.

Scyboz, G: le contrat de garantie et le cautionement, Fribourg 1979.

Sirmen, L: Alacak Rehni, Ankara 1990.

Sirmen, L: Türk Özel Hukukunda \$art, Ankara 1992.

Staehelin, A: Zur Abtretung künftiger Forderungen, Mélanges Pierre Engel, Lausanne 1989, sh. 381 vd.

Sungurbey, I: Borģ İkran ve Borģ Vaadi, İstanbul 1957.

Tandoğan, H: Borģlar Hukuku, Özel Borģ iliskkileri. C. II, Ankara 1987. 
Tuor/Schnyder: Schweizerisches Zivilgesetzbuch, 10. Aufl. Zürich 1986.

Únal, M: Şekli E Eya Hukuku, Ankara 1989.

von Büren, B: Schweizerisches Obligationenrecht, Allgemeiner Teil, Zürich 1964.

von Tuhr/Peter: Allgemeiner Teil des schweizerischen Obligationenrecht, Bd. I/1, Zürich 1974.

von Tuhr/Escher: Allgemeirer Teil des sshweizerischen Obligationeniechts. Bd. II, 3. Aufl, Zürich 1974.

Walder, H.U.: Lohnabtretung und Zwangsvollstreckung, Zürich 1974.

Waelli, P: Das reine fiduziariszhe Rechtsgeschaeft, Diss. Zü)i'hc 1969.

Wiegand, W: Fidïziarische Rechtsgeschaeft, ZBJV 116/1980, sh. 537 vd.

Wiegand, W: Kredisicherung und Rechtsdogmatik, in: Berner Festgabe zum schweizerischen Juristentag, Bern 1979, sh. 283 vd.

Wieland, C: les droits reels dans le code sivil suisse, T. I-II, Paris, Paris 1913-1914.

Wolff, M. Wesen und Voraussetzung der zession, Zürich 1917.

Zobl, D: Berner Kommentar, IV/2/5/1, Das Fahmispfand, Systematischer Teil und Ant. 884-887 ZGB, Bern 1982.

Zobl, D: Die Globalzession im Lichte der neueren Lehre und Rechtssprechung-eine Standortbestimmung, SJZ 1989, sh. 349 vd. 